\title{
Review
}

\section{Association between protein feeding and reproductive efficiency in the dairy cow: specific emphasis on protein feeding in Finland}

\author{
Kevin John Shingfield \\ Agricultural Research Centre of Finland, Animal Production Research, FIN-31600 Jokioinen, Finland, \\ e-mail: kevin.shingfield@mtt.fi
}

Marjatta Jokela

Valio Ltd, Farm Services and Member Relations, PO Box 30, FIN-00039 Helsinki, Finland. Current address: Ministry of Agriculture and Forestry, Department of Agriculture, PO Box 232, FIN-00171 Helsinki, Finland

Kaisa Kaustell and Pekka Huhtanen

Agricultural Research Centre of Finland, Animal Production Research, FIN-31600 Jokioinen, Finland

Juha Nousiainen

Valio Ltd, Farm Services and Member Relations, PO Box 30, FIN-00039 Helsinki, Finland

\begin{abstract}
Associations between protein feeding and reproductive efficiency in the dairy cow are reviewed. Examination of published data indicated that reproductive responses assessed as days open, services per conception or conception rate following changes in protein feeding tend to be inconsistent. Discrepancies can arise due to between-study variations in experimental design, statistical analysis, sample population size, uterine health, cow age, parity, reproductive management or nutrient intake. Detrimental effects on reproductive efficiency following periods of excessive protein feeding are often attributed to increases in tissue urea and ammonia concentrations leading to impaired reproductive physiology, modified endocrine function or exacerbated postpartum negative energy balance. Examination of data collected from Finnish dairy herds $(n=16051)$ participating in the national milk recording scheme during 1993 indicated that milk production was maximised in herds fed diets containing $180 \mathrm{~g}$ crude protein/kg dry matter. In contrast, no consistent relationships were identified between increases in on-farm protein feeding necessary to secure higher milk production and herd reproductive efficiency assessed as calving interval, first service interval and number of inseminations per calving. Further examination of data derived from 5437 herds within the National recording scheme indicated that on-farm reproductive efficiency was independent of large variations in the mean annual urea concentration of bulk tank milk. It is concluded that increases in the crude protein content of Finnish dairy cow rations from 150 to between 170 and $180 \mathrm{~g} / \mathrm{kg}$ dry matter would allow improvements in milk production to be realised without leading to significant reductions in reproductive efficiency.
\end{abstract}

Key words: dairy cow, dietary protein, reproductive efficiency, urea 
Shingfield, K.J. et al. Protein feeding and reproductive efficiency

\section{Introduction}

Over recent years considerable emphasis has been placed on protein feeding of the dairy cow, since protein is typically the most expensive feed ingredient, milk payments tend to favour the production of milk protein and excessive nitrogen (N) excretion has a detrimental affect on the environment (Broderick and Clayton 1997). Producers attempting to increase milk production, may consider the use of protein supplements, since increases in dietary crude protein (CP) content often elicit positive milk production responses (e.g. Thomas and Rae 1988, Chamberlain et al. 1989). Recently, Huhtanen (1998a) using data from 7 Finnish production studies reported that dietary inclusion of $1 \mathrm{~kg}$ (on an airdry basis) of rapeseed meal elicited mean milk and milk protein yield responses of 1050 and 39.4 $\mathrm{g} / \mathrm{d}$, respectively. Protein feeding also has an impact on reproductive efficiency, and has been reported to be decreased in cows fed diets containing either low (e.g. Hibbitt 1984) or high (e.g. Edwards et al. 1980, Kaim et al. 1983, Canfield et al. 1990) protein contents. Supplementary protein feeding equivalent to increases in dietary concentrations of between 30 and $65 \mathrm{~g} / \mathrm{kg}$ dry matter (DM) have often been associated with depressions in reproductive efficiency (e.g. Jordan and Swanson 1979a, Folman et al. 1981, Chalupa 1984, Canfield et al. 1990). However, reproductive efficiency has been also been reported to be unaffected by increases in dietary $\mathrm{CP}$ content of $50 \mathrm{~g} / \mathrm{kg}$ DM (Howard et al. 1987) and $70 \mathrm{~g} / \mathrm{kg}$ DM (Carroll et al. 1988).

Following ingestion by ruminant animals, dietary CP is catabolised to ammonia via microbial proteases. Intakes of rumen degradable or undegradable protein in excess of requirements can result in increases in ammonia, urea and other unidentified nitrogenous compound concentrations in body tissues. Increased concentrations of nitrogenous compounds liberated during rumen and tissue nitrogen metabolism in the reproductive tract have been considered to exert detrimental affects on reproductive organ function and modify tissue responses to reproductive hormones (Ferguson and Chalupa 1989). Overfeeding of protein has also been suggested to indirectly impair reproductive performance by exacerbating negative energy balance during early lactation due to increased energy requirements for ureogenesis (Chalupa 1984, Oldham 1984).

The aim of the current paper is to review the relationship between protein feeding and reproductive efficiency in the dairy cow and the potential underlying physiological mechanisms accounting for altered reproductive responses. Based on data collected from the national milk recording scheme during 1993, the potential impact of increases in on-farm protein feeding and associated changes in the urea concentration of bulk tank milk on the reproductive efficiency of Finnish dairy herds was assessed.

\section{Protein feeding}

During the last decade several new protein evaluation systems have been proposed (e.g. Agricultural and Food Research Council 1992, Madsen et al. 1995) in order to improve the accuracy of protein feeding to ruminant animals by accounting for both microbial and host tissue $\mathrm{N}$ metabolism. A common feature of new protein evaluation systems is the differentiation of dietary $\mathrm{N}$ that is degraded in the rumen, and that which escapes degradation and enters the small intestine for subsequent digestion and absorption. Despite variations in the proportion of $\mathrm{N}$ in the form of either true or non-protein $\mathrm{N}$ between ruminant feeds, protein systems currently evaluate feeds in terms of total $\mathrm{N}$ or $\mathrm{CP}$ content defined as $6.25 \times \mathrm{N}$.

\section{Measurement of rumen nitrogen degradability}

Once ingested, dietary CP is subjected to microbial catabolism the extent of which is dependent 
Vol. 8 (1999): 365-392.

upon rumen environment and the physical properties of a particular protein (Czerkawski 1986). Obtaining reliable estimates of the extent of $\mathrm{N}$ degradation by rumen microbes is extremely difficult, due to variations both within and between feeds and the rumen environment (Cottrill 1993). Several methods have been used to provide estimates of rumen $\mathrm{N}$ degradability. In vivo measurements of degradable $\mathrm{N}$ calculated as the difference between $\mathrm{N}$ intake and the sum of endogenous and microbial $\mathrm{N}$ entering the small intestine, are scientifically the most sound but require the use of surgically modified animals and microbial and digesta markers. Although in-vivo procedures are subject to error due to problems associated with the determination of microbial $\mathrm{N}$ flow (Broderick and Merchen 1992), and are inappropriate for routine feed degradability measurements they are necessary to provide reference values in order to validate alternative in vitro methods (NRC 1985).

The in situ method is probably the most widely used procedure to determine rumen $\mathrm{N}$ degradability. This approach proposed by Mehrez and Ørskov (1977) involves incubating feed samples in nylon bags and suspending them for a period of time (typically $48 \mathrm{~h}$ ) in the rumen of sheep or cattle. Rumen $\mathrm{N}$ degradability is estimated as the difference in bag $\mathrm{N}$ content following incubation, and allows the rate of $\mathrm{N}$ disappearance of an individual feed to be determined. Combining the rate of $\mathrm{N}$ disappearance and an appropriate estimate of rumen outflow rate allows the effective rumen $\mathrm{N}$ degradability (Ørskov and McDonald 1979) to be estimated. With the exception of the protein evaluation system adopted in France, tabulated values of feed $\mathrm{N}$ degradability necessary to assist formulation of ruminant diet have been estimated using the in situ method. Despite being widely used the method does have limitations. Criticisms levelled at the technique include the lack of reduction in incubated feed particle size through chewing and rumination, an incorrect assumption that $\mathrm{N}$ disappearing from the bag at $0 \mathrm{~h}$ incubation time is immediately degraded and insufficient method standardisation (Nocek 1988, Michalet-Doreau and Ould-Bah 1992).
Huhtanen et al. (1998) recently demonstrated that microbial enzyme activities inside nylon bags can be as low as proportionately 0.10 of that in rumen ingesta.

Requirements for surgically modified animals and associated limitations in terms of time and cost mean that both in vivo and in situ methods cannot be considered for routine evaluation of feed N degradability (Cottrill 1993). Consequently there has been drive to develop in vitro methods to estimate $\mathrm{N}$ degradability of a feed. In vitro approaches can be characterised as either attempting to determine $\mathrm{N}$ solubility in various solvents based on the assumption that this is closely related to rumen degradability or the simulation of $\mathrm{N}$ degradation by incubation of feeds with either mixed or single strains of bacteria. The merits and demerits of the in vitro approach to estimate $\mathrm{N}$ degradability are well documented (refer to NRC 1985, Nocek 1988, Cottrill 1993).

\section{Protein feeding in Finland}

Dairy cow diets tend to be formulated from a wide range of ingredients, due to variations in feed cost and availability and the value of milk within milk payment schemes. Consequently, relatively large differences in the protein content of dairy cow rations can exist between individual countries. Finnish dairy cow rations typically contain lower amounts of protein $(150 \mathrm{~g}$ CP/kg DM; Kaustell et al. 1998) than diets fed in other European countries, such as Holland (185-220 g/kg DM, Tamminga 1992) or the United Kingdom (180-190 g/kg DM, N.W. Offer, personal communication).

Formulation of ruminant diets typically involves a computer assisted coupling of calculated protein requirements with tabulated feed values. In Finland, protein feeding of ruminant animals based on digestible crude protein (ARC 1965) was replaced in 1995 by a new system that defines dietary protein in terms of amino acids absorbed in the small intestine (AAT) and protein balance in the rumen $(\mathrm{PBV}$; Tuori et al. 


\section{Shingfield, K.J. et al. Protein feeding and reproductive efficiency}

1998). The term AAT describes the amount of amino acids derived from microbial protein and undegraded feed protein digested in the small intestine, while PBV describes rumen $\mathrm{N}$ availability relative to microbial requirements.

Protein feeding recommendations based on the Finnish AAT-PBV system differ from those calculated according to AAT-PBV systems (Madsen et al. 1995) adopted in other Nordic countries. Differences arise because dietary digestible carbohydrate and rumen degradable protein content are used to predict microbial protein supply and lower feed particle outflow rates from the rumen are used to calculate effective rumen protein degradability. Incorporating these modifications has been shown to allow accurate predictions of dietary protein value (Tuori et al. 1998). Protein values assigned to diets according to the Finnish AAT-PBV system have been shown to be closely correlated $(\mathrm{r}=0.977, \mathrm{n}=$ 67) with yields of milk protein (Huhtanen 1998b), indicating that production responses following changes in protein feeding can be predicted accurately. There is however, also an urgent need to establish potential effects of protein feeding on reproductive efficiency, to ensure that protein intakes considered optimal for milk production are not associated with significant depressions in reproductive performance.

\section{Association between protein feeding and reproductive efficiency}

The association between protein feeding of ruminant livestock and reproductive performance is a concern in many countries. However there is a clear distinction between Third World and developed countries. In most developing countries ruminants have to survive on poor quality feeds which are deficient in numerous nutrients, particularly protein. As a result, reproductive efficiency of ruminant livestock in these countries is generally constrained by a deficiency in dietary protein supply (Kaur and Arora 1995). In developed countries, the situation is reversed such that excessive intakes of dietary protein have often been implicated in situations of reproductive inefficiency (e.g. Canfield et al. 1990, Elrod and Butler 1993).

\section{Protein deficiency}

Since reproduction responses to protein deficiency have been considered in detail in several published reviews (Kaur and Arora 1995, Robinson 1990) associations between reproductive efficiency and low dietary protein intakes are discussed in brief. Provision of an adequate supply of nutrients during the pre and postpartum period is paramount to securing reproductive performance. It is well established that optimal ovulation rates can only be achieved when animals receive sufficient supplies of energy and protein (Henniawati and Fletcher 1986). A deficiency of dietary protein can result in poor reproductive performance due to ovarian dysfunction or increases in embryo mortality. Due to disturbances of ovarian function, protein deficiency is often manifested as protracted postpartum anoestrus or as a delayed or extended oestrus. Protein deficiency can markedly increase anoestrus in crossbred cows by as much as $140 \mathrm{~d}$ (Juneja and Arora 1989). Protracted anoestrus represents a major cause of reproductive inefficiency, such that reducing the interval between parturition and rebreeding has been suggested to be the most feasible means of improving reproductive efficiency in cattle (Robinson 1990). Feeding diets containing sufficient protein is a prerequisite for reducing the parturition-rebreeding interval, since oestrus is often delayed in protein deficient animals. Sasser et al. (1988) noted that the incidence of behavioural oestrus was reduced by $29 \%$ and delayed on average by $11 \mathrm{~d}$ in primiparous beef cows fed diets deficient in protein (77 $\mathrm{g} \mathrm{CP} / \mathrm{kg} \mathrm{DM}$ ) compared to control diets containing $225 \mathrm{~g} \mathrm{CP} / \mathrm{kg} \mathrm{DM}$. In addition to delayed resumption of normal oestrus cyclicity, protein deficiency reduced conception rate at first serv- 
Vol. 8 (1999): 365-392.

ice (25 and $71 \%$ for low and high protein diets, respectively) and the incidence of pregnancy (respective values of 32 and $74 \%$ ).

Cows deficient in protein can also develop hypoalbuminaemia a condition inversely related to the number of services per conception (Payne et al. 1970). Protein feeding is also central to embryo survival and foetal development, since inadequate supplies have been reported to cause a significant reduction in embryo survival and development (Folman et al. 1983, Robinson 1986, Kaur and Arora 1995).

\section{Excessive protein intake}

In order to attain high levels of milk production, dairy cows in developed countries are typically fed high CP diets. Use of high protein intakes to promote milk production can however, have adverse effects on subsequent reproduction (Oldham 1984). It is becoming increasing apparent that high as well as low intakes of dietary protein appear to be associated with reproductive disturbances. In developed countries, impaired reproductive performance is more often associated with excessive intakes of protein (Kaur and Arora 1995).

Feeding excessive amounts of protein to dairy cows can impair reproductive efficiency without inducing changes in oestrus (Kaim et al. 1983). Canfield et al. (1990) reported that conception rate at first service was significantly reduced in cows fed high protein diets (192 g CP/ $\mathrm{kg}$ DM) compared to animals fed diets containing only moderate levels (165 g CP/kg DM). Impaired reproduction efficiency following changes in dietary $\mathrm{CP}$ content may be associated with changes in uterine environment, since dietary CP content had only minor effects on days to first ovulation, days to first service or luteinizing hormone secretion. However, diets deficient in energy can also lead to decreased conception rates (e.g. Butler and Elrod 1991).

Examination of published data indicates that feeding diets containing large amounts of $\mathrm{CP}$ is often associated with increases in days open and services per conception (Table 1). However, the extent of these responses to increases in dietary $\mathrm{CP}$ content tend to be inconsistent, and in some cases increases in dietary $\mathrm{CP}$ content have reduced the number of services per conception (Chandler et al. 1976, Hibbitt 1984). Increases in dietary protein content have also been negatively associated with conception rate, but as with other measures of reproductive efficiency these responses tend to be inconsistent (Fig. 1). Most studies of reproductive efficiency in the dairy cow have identified a negative association with increases in protein feeding (e.g. Kaim et al. 1983, Canfield et al. 1990). In contrast, other studies have reported that feeding diets containing CP concentrations excess of $195 \mathrm{~g} / \mathrm{kg}$ DM has only minor effects on conception rate (Howard et al. 1987, Carroll et al. 1988, Bruckental et al. 1989, Barton et al. 1996).

\section{Protein degradability}

Detrimental effects of excessive protein feeding on reproductive efficiency have often been linked with the intake of CP that is degraded in the rumen (Folman et al. 1981, Ferguson et al. 1988, Canfield et al. 1990, Butler 1998). Based on one study, Carroll et al. (1988) proposed that reproductive management, rather than the intake of dietary $\mathrm{CP}$ either degraded or escaping rumen catabolism was more likely to account for variations in reproductive efficiency. However, this suggestion is inconsistent with data of Elrod and Butler (1993) indicating that excessive intakes of rumen degradable protein decreased reproductive efficiency of cows managed under conditions considered optimal.

Reproductive efficiency, expressed as the proportion of primiparous beef cattle served during first oestrus has also been shown to improve following postpartum protein feeding in excess of predicted requirements, provided it escapes extensive degradation in the rumen (Wiley et al. 1991). In another study with beef cattle, Rusche et al. (1993) reported that reproductive performance was independent of changes in protein 


\section{Shingfield, K.J. et al. Protein feeding and reproductive efficiency}

Table 1. Associations between dietary crude protein content with days open and services per conception reported in the literature.

\begin{tabular}{|c|c|c|c|c|c|}
\hline \multirow{2}{*}{$\begin{array}{l}\text { Reproduction } \\
\text { parameter }\end{array}$} & \multicolumn{4}{|c|}{ Dietary crude protein content (g/kg DM) } & \multirow[t]{2}{*}{ Reference } \\
\hline & $120-145$ & $145-165$ & $165-190$ & $190-220$ & \\
\hline \multicolumn{6}{|l|}{ Days open } \\
\hline & 130 & 140 & & & Chandler et al. 1976 \\
\hline & 69 & 96 & & 106 & Jordan and Swanson 1979a \\
\hline & 123 & 141 & 139 & & Edwards et al. 1980 \\
\hline & & $84-98$ & & 102 & Folman et al. 1981 \\
\hline & & 82 & 127 & & Piatkowski et al. 1981 \\
\hline & & 80 & 80 & & Howard et al. 1987 \\
\hline & 72 & & & 82 & Carroll et al. 1988 \\
\hline & 71 & & & 81 & Barton et al. 1996 \\
\hline \multicolumn{6}{|c|}{ Services per conception } \\
\hline & 2.4 & 2.1 & & & Chandler et al. 1976 \\
\hline & 1.5 & 1.9 & & 2.5 & Jordan and Swanson 1979a \\
\hline & 2.3 & 2.6 & 2.7 & & Edwards et al. 1980 \\
\hline & & $1.5-1.8$ & & 2.3 & Folman et al. 1981 \\
\hline & & 2.0 & 2.8 & & Piatkowski et al. 1981 \\
\hline & & 1.8 & & 2.3 & Kaim et al. 1983 \\
\hline & & 1.4 & 1.4 & & Howard et al. 1987 \\
\hline & 1.5 & & & 1.8 & Carroll et al. 1988 \\
\hline & & 2.3 & & $2.1-2.7$ & Bruckental et al. 1989 \\
\hline & & 1.2 & & 1.6 & Elrod and Butler 1993 \\
\hline & 1.7 & & & 1.8 & Barton et al. 1996 \\
\hline
\end{tabular}

source or intake. Based on their findings, Elrod and Butler (1993) proposed that depressions in reproductive efficiency associated with exces- sive intakes of degradable protein were mediated via an unidentified mechanism leading to a decrease in uterine $\mathrm{pH}$ during the luteal phase.

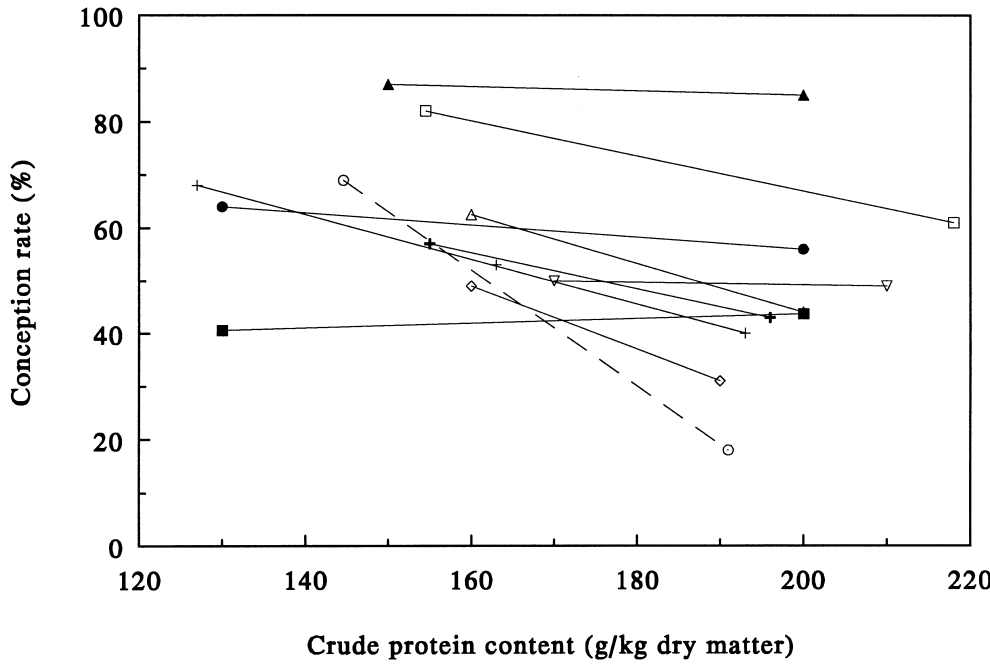

Fig. 1. Association between dietary crude protein content and conception rate reported in the literature. Data derived from Jordan and Swanson 1979a (+), Folman et al. $1981(\triangle)$, Piatkowski et al. 1981 (o), Kaim et al. 1983 (+), Howard et al. 1987 ( $\mathbf{\Delta})$, Carroll et al. 1988 (О), Bruckental et al. $1989(\nabla)$, Canfield et al. $1989(\diamond)$, Elrod and Butler 1993 ( $\square$ ) and Barton et al. 1996 
Vol. 8 (1999): 365-392.

Further studies have shown that high intakes of rumen degradable protein before ovulation and during early pregnancy period can adversely affect embryo survival in non-lactating ewes (Bishonga et al. 1994), but not in all cases. Wallace et al. (1996) reported that feeding additional rumen degradable nitrogen in the form of urea supplements during pre, peri and post-ovulation periods had no influence on fertilisation rate, embryo survival or luteotropic protein secretion. In contrast, a more recent study demonstrated that feeding excess rumen degradable protein decreased ovarian follicular development, delayed postpartum luteal activity and reduced the accumulation of luteal tissue (Garcia-Bojalil et al. 1998). However, these findings are equivocal because dietary supplements of rumen protected long chain fatty acids leading to an increase in energy intake augmented the decline in luteal tissue development, doubled the number of corpora lutea and reduced the interval to the first rise in progesterone by $6 \mathrm{~d}$. Furthermore, the inclusion of protected fat was also associated with an increase in the incidence of pregnancy from 52 to $86 \%$, suggesting that negative effects attributed to rumen degradable protein may have reflected changes in the extent of energy deficiency or energy status.

\section{Feeding management}

Carroll et al. (1988) proposed that the method of feeding may indirectly influence reproductive efficiency, since rumen ammonia concentrations may be more stable in cows fed a total mixed ration, preventing surges of ammonia entering the peripheral circulation. Hepatic extraction and metabolic conversion of ammonia absorbed from the rumen appears to be more efficient when rumen ammonia concentrations accumulate steadily over time compared to rapid increases. Continuous intraruminal infusions of urea in dairy cows have been shown to elicit progressive increases in urea concentrations of peripheral blood, but concentrations of ammonia have remained unaffected until the capacity for hepatic conversion is exceeded (Choung et al. 1990). In the same study, twice-daily administration of non-toxic urea doses caused ammonia concentrations in peripheral blood to increase substantially 3-4 h post infusion. Increases in the appearance of ammonia in peripheral blood are thought to occur as a result of 'leakage' through the liver (Bartley et al. 1981) or transfer of ammonia via non-hepatic routes (Chalmers et al. 1976).

Protein contained in grass silage is rapidly and extensively degraded in the rumen (Huhtanen 1998a) and digestion of diets containing large proportions of grass silage is characterised by an inefficient rumen microbial utilisation of silage N, leading to substantial amounts of ammonia absorption from the rumen (Chamberlain et al. 1986). Consequently, a clear association between reproductive efficiency and silage quality might be expected. Gustafsson and Carlsson (1993) conducted a field study with 29 Swedish dairy herds and reported that feeding silage with high ammonia concentrations increased the interval between calving and conception, but not the interval between calving and first service. Based on these findings they concluded that protein quality could be at least as important as dietary CP content in determining reproductive efficiency. However, reduced reproductive responses attributed to ammonia content and hence silage protein quality may be better explained by associated reductions in silage DM intake leading to an exacerbation of postpartum negative energy balance or as a result of potentially toxic amine intakes (Tveit et al. 1992).

Due to the general assumption that microbial synthesis is often constrained by a mismatch in rumen energy and $\mathrm{N}$ availability for microbial growth there has been considerable interest in the potential of manipulation of the rate of carbohydrate fermentation to improve the efficiency of $\mathrm{N}$ capture by rumen microbes. Theoretically at least, manipulating the rate of rumen carbohydrate fermentation by inclusion of different ingredients in ruminant rations is extremely attractive since it may allow the potential negative impact of high intakes of rumen degrada- 


\section{AGRICULTURAL AND FOOD SCIENCE IN FINLAND}

\section{Shingfield, K.J. et al. Protein feeding and reproductive efficiency}

ble protein on reproductive efficiency to be minimised. However, experimental evidence used to support an increase in microbial production attributable to improved synchrony of energy and $\mathrm{N}$ release in the rumen (e.g. McCarthy et al. 1989, Sinclair et al. 1993) is questionable. The major criticism of these studies is that interpretation of differences in the degree of rumen energy and $\mathrm{N}$ synchronicity is confounded with the use of different ingredients to formulate experimental diets (Chamberlain and Choung 1995). Subsequent experiments have lead to the general conclusion that there is no real advantage in attempting to enhance microbial protein supply by synchronising energy and $\mathrm{N}$ release in the rumen (Henning et al. 1993, Kim et al. 1999). Henning et al. (1993) suggested that formulation of ruminant diets should be directed towards providing an even release of energy in the rumen. In the absence of direct experimental evidence to the contrary, the scope of feeding strategies attempting to optimise or maintain reproductive efficiency by manipulation of the rate of energy and $\mathrm{N}$ release in the rumen appears to be limited.

\section{Negative energy balance}

Dietary deficiencies of energy and/or protein are the most common predisposing factors for prolonging the interval between calving and first oestrus (Kaur and Arora 1995). Nutrient supply has a major role in the initiation of postpartum ovarian cyclicity. During early lactation, energy intake is insufficient to meet energy requirements for maintenance and potential milk production (Garnsworthy 1988). Deficits in energy intake are to some extent compensated for by tissue catabolism, principally intermuscular, subcutaneous and internal fat stores (Butler-Hogg et al. 1985). When energy expenditure exceeds energy intake a situation generally referred to as negative energy balance exists, and typically reaches a maximum during the first 7 to $14 \mathrm{~d}$ postpartum and subsequently recovers at a variable rate. Periods of negative energy balance also tend to coincide with the time of first insemination necessary to secure pregnancy during early lactation, and appear to be directly related to first service intervals and lowered conception rates (Butler and Smith 1989). Initiation of the ovarian cycle tends to occur once the energy nadir returns towards balance (Butler et al. 1981), such that the extent and duration of negative energy balance is currently thought to regulate the return of normal ovarian activity following calving. High yielding dairy cows can remain in negative energy balance during the first $70 \mathrm{~d}$ of lactation (Villa-Godoy et al. 1988). Onset of postpartum ovulation has been suggested to be delayed by $0.67 \mathrm{~d}$ per MJ of negative energy status experienced during the first $20 \mathrm{~d}$ postpartum (Butler and Smith 1989). Energy deficiency (Villa-Godoy et al. 1988, Butler and Smith 1989) or loss of live weight (McClure 1970, Heinonen et al. 1988) at service can impair reproductive efficiency.

Chalupa (1984) and Oldham (1984) considered that excess protein feeding exerts deleterious effects on fertility by exacerbating negative energy balance during early lactation, since hepatic conversion of ammonia to urea would increase metabolisable energy requirements by 48 $\mathrm{KJ} / \mathrm{g}$ excess N (NRC 1988). Despite limited experimental evidence the role of excessive protein intake on negative energy balance has generally been accepted and often suggested to account for differential reproductive responses to increases in protein feeding (e.g. Ferguson and Chalupa 1989, Kaur and Arora 1995, Butler 1998). However, a number of experimental observations tend to challenge this hypothesis, since there is overwhelming evidence that increases in dietary $\mathrm{CP}$ content generally improve DM intake and often diet digestibility (e.g. Oldham 1984, Thomas and Rae 1988, Chamberlain et al. 1989, Huhtanen 1998a). Furthermore, protein supplementation of grass silage based diets has also been observed to improve live weight gain (Huhtanen and Heikkilä 1996) but have no effect on plasma $\beta$-hydroxybutyrate (Heikkilä et al. 1998) or non-esterified fatty acid concentrations (Rinne et al. 1995), findings inconsistent 
Vol. 8 (1999): 365-392.

with exacerbated postpartum negative energy balance.

Secretion of insulin, a major metabolic regulator of plasma glucose concentration is highly dependent on nutrient supply, being modified in the presence of various metabolic stimuli including glucose, volatile fatty acids and amino acids (Brockman and Laarveld 1986). Glucose is a more potent stimulator of insulin secretion than propionate the major gluconeogenic substrate in ruminants (Kelly et al. 1993) while increases in ammonia in peripheral blood appear to be associated with reduced insulin and increased glucose concentrations (Choung et al. 1990). During periods of postpartum negative energy balance, plasma insulin and glucose concentrations tend to become depressed (Ferguson and Chalupa 1989), and can potentially modify hypothalamo-hypophyseal-ovarian axis function (e.g. Rutter and Manns 1987). Tissue culture studies have demonstrated that increases in insulin concentration can stimulate follicle stimulating hormone secretion by pituitary cells (Adashi et al. 1981) and luteal production of progesterone (Ladenheim et al. 1984). These findings suggest that effects due to changes in energy balance may be mediated by insulin and is consistent with studies indicating that the probability of conception is reduced in cows with low postpartum blood glucose concentrations (e.g. Plym Forshell et al. 1991, Pehrson et al. 1992). However, resumption of ovarian activity appears to be more dependent on the duration rather than the extent of depressed glucose concentrations (Miettinen 1991).

Dietary intakes of protein and energy typically considered independently to simplify ration formulation, can be misleading since energy supply has profound effects on the efficiency of $\mathrm{N}$ utilisation, while amino acids can be utilised for gluconeogenesis or adenosine triphosphate synthesis (Oldham 1984). Despite a lack of experimental evidence to suggest that high protein intakes have detrimental effects on ovarian follicular development, ovulation or oocyte fertilisation (Blanchard et al. 1990, Garcia-Bojalil et al. 1994) interactions between protein and energy supply have been implicated in cases of impaired embryo development (Butler 1998). Although the relative significance of both energy and protein intake and their interactions remain unresolved, deficiencies in energy intake during periods of excessive protein feeding do appear to increase associated risks of reproductive inefficiency. For example, Howard et al. (1987) reported no differences in reproductive efficiency of cows fed moderate (145 g/kg DM) or high CP (194 g/kg DM) diets. In their study, Butler and Elrod (1991) fed diets supplying proportionately 0.7 of calculated energy requirements and reported that increases in dietary $\mathrm{CP}$ concentrations from 150 to $210 \mathrm{~g} / \mathrm{kg} \mathrm{DM}$, were associated with a decline in conception rate from 83 to $62 \%$.

Mechanisms by which energy balance induces changes in the activity of the hypothalamohypophyseal-ovarian axis remain unresolved (Canfield et al. 1990). Since changes in endocrine function in cows fed energy deficient diets are similar to those reported in cows fed high $\mathrm{CP}$ diets, effects on reproduction attributed to protein feeding could reflect changes in energy status (Ferguson and Chalupa 1989). It is crucial that future experimentation, examining relationships between protein feeding and reproductive efficiency effectively account for variations in energy balance during early lactation.

\section{Experimental design}

Discrepancies in conception rate responses to changes in dietary CP content may to some extent be explained by between-study differences in experimental design and subsequent analysis of experimental data. Reproductive responses may be biased or invalid if reproductive management protocols, or sire and dam factors are not balanced across protein feeding treatments within experiments. Ferguson and Chalupa (1989) suggested that variations in management and sire factors within a study could be more effectively taken into account than dam factors. Experimental animals used in reproduction stud- 


\section{AGRICULTURAL AND FOOD SCIENCE IN FINLAND}

\section{Shingfield, K.J. et al. Protein feeding and reproductive efficiency}

ies are typically assigned to protein treatments based on previous milk production, parity, condition score and in some cases previous reproductive history. Since health disorders such as uterine infection (metritis) and ovarian cysts are major causes of reproductive inefficiency (Oltenacu et al. 1984), it is essential that cows with a history of such conditions are equally distributed between treatments in order to minimise bias due to dam. Reproductive responses may also be misleading due to interactions between biological and management factors and variations in energy intake or energy balance.

Use of sufficient experimental animals per protein treatment is also vital to allow an accurate assessment of associations between protein feeding and reproductive efficiency. The number of animals per treatment required is dependent on the homogeneity and reproductive potential of the sample population and the extent of differential reproductive responses expected to be identified. Ferguson and Chalupa (1989) reported that a minimum of between 20 to 25 and between 80 and 100 cows per treatment would be required to statistically validate differential conception rate responses of 20 and $10 \%$, respectively. Clearly, many studies have used insufficient numbers of cows per treatment to allow a reliable assessment of the influence of dietary $\mathrm{CP}$ content on reproductive efficiency.

Variations in energy intake and energy balance between-studies are often impossible to reconcile, simply because energy contents of experimental diets are in many cases not reported. Furthermore, mobilisation of energy reserves appears to be dependent on absorbed amino acid supply. Whitelaw et al. (1987) demonstrated that abomasal infusions of casein stimulated the mobilisation of body fat stores commensurate with an increase in milk yield. Improvements in milk production continued until $\mathrm{N}$ equilibrium was achieved after which catabolism of excess protein resulted in a change of carbohydrate and endocrine status causing a repartitioning of nutrients towards body tissues rather than milk synthesis. Inefficient utilisation of additional dietary protein can increase tissue urea concentra- tions (Whitelaw et al. 1987, Metcalf et al. 1996), alter the composition of uterine fluid (Jordan et al. 1983) and reduce intrauterine $\mathrm{pH}$ (Elrod and Butler 1993, Elrod et al. 1993). Consequently, the impact of increases in protein feeding on reproductive efficiency may potentially be related to marginal milk protein yield responses. Folman et al. (1981) noted that increases in dietary $\mathrm{CP}$ content of $40 \mathrm{~g} / \mathrm{kg} \mathrm{DM}$, reduced conception rate, increased days open and decreased milk protein synthesis. Piatkowski et al. (1981) reported that increases in dietary $\mathrm{CP}$ concentrations of $46 \mathrm{~g} / \mathrm{kg}$ DM caused a decrease in conception rate of $51 \%$, and was associated with a marginal milk protein yield response of $0.063 \mathrm{~g}$ $\mathrm{g}^{-1}$. In a similar study, Bruckental et al. (1989) evaluated the influence of increases of $40 \mathrm{~g} \mathrm{CP} /$ $\mathrm{kg}$ DM following dietary supplementation with either soya bean or fish meal on reproductive performance. Compared to the basal diet (48\%), inclusion of soya bean and fish meal were associated with mean conception rates of 43 and $52 \%$, respectively. The magnitude of conception rate responses to increased protein intake derived from soya bean meal and fish meal were consistent with the extent of marginal milk protein yield responses $\left(0.056\right.$ and $0.180 \mathrm{~g} \mathrm{~g}^{-1}$, respectively).

Ferguson and Chalupa (1989) evaluated conception rate responses to changes in dietary $\mathrm{CP}$ content using logistic regression analysis. Based on this approach, data collected from 7 studies indicated that differential conception rate responses could be better explained by variations in rumen degradable protein intake than differences due to dam or reproductive management factors. Furthermore, predicted conception rates were found to be independent of dietary CP content, but decreased with increased rumen degradable protein intake. Relationships between reproductive efficiency and protein feeding may also to be confounded by variations in uterine health, age, parity, energy and the intake of undegraded protein. Ferguson and Chalupa (1989) concluded that changes in dietary $\mathrm{CP}$ content per se may only elicit minor and often inconsistent effects on conception rate, but adverse effects 
Vol. 8 (1999): 365-392.

may occur in relatively old cows or those experiencing post-calving complications. When attempting to resolve discrepancies in reproductive responses to changes in dietary CP content, it appears that the age of the cow must be taken into account. Bruckental et al. (1989) demonstrated that increases in dietary CP content from 170 to $216 \mathrm{~g} / \mathrm{kg}$ DM caused a delay in the onset of first oestrus and decrease pregnancy rate in cows in their fourth or later lactation.

\section{Potential negative effects of excessive protein feeding on reproductive performance}

\section{Toxicity and physiological impairment of reproductive tissues}

Ammonia produced from microbial degradation of dietary $\mathrm{CP}$ is removed from the rumen as the result of incorporation into microbial protein, absorption through the rumen wall and outflow via rumen fluid (Bodeker et al. 1990). Since, free ammonia or ammonium ions are toxic to mammalian cells (Visek 1984) potential toxicity is prevented by conversion to urea in the liver. However, hepatic ureogenesis is limited (Symonds 1981, Choung et al. 1990) and once exceeded concentrations of ammonia in peripheral blood can approach or exceed toxic levels.

High blood ammonia concentrations have been suggested to cause a suppression of the immune system (Carroll et al. 1988). Klucinski and Targowski (1984) found that sub-toxic concentrations of ammonia $(80-160 \mu \mathrm{mol} / \mathrm{l}) \mathrm{de}-$ pressed bovine lymphocyte responses to $\mathrm{mi}$ togens. Reduced immune function has been suggested to account for increased metritis in cows fed high (200 g/kg DM) compared to low CP $(130 \mathrm{~g} / \mathrm{kg} \mathrm{DM})$ diets due to a delay in the clearance of uterine contaminants (Anderson and Barton 1987; ref. Ferguson and Chalupa 1989).
Jordan et al. (1983) noted that feeding a low or high CP diet (120 vs. 230 g/kg DM) caused significant differences in plasma ammonia concentration (105 vs. $133 \mu \mathrm{mol} / \mathrm{l})$. Potential detrimental effects on reproductive efficiency attributed to ammonia toxicity could be misleading however, since analytical procedures do not distinguish between non-ionic $\left(\mathrm{NH}_{3}\right)$ and ionic $\left(\mathrm{NH}_{4}^{+}\right)$ forms of ammonia (Visek 1968). Despite being relatively low at physiological $\mathrm{pH}$, non-ionic ammonia concentrations $(0.16$ and $0.25 \%$ of total ammonia, Jacques et al. 1959) are primarily responsible for the toxic effects of ammonia. As a result, biologically significant changes in plasma ammonia concentrations may not be revealed by routine determinations (Visek 1984).

Feeding high CP diets can result in an increase in urea concentrations in the bovine reproductive tract (Jordan et al. 1983, Duby et al. 1984, Carroll et al. 1988) and elevate vaginal and uterine ammonia concentrations (Jordan et al. 1983). In vitro studies have demonstrated that aqueous solutions of urea (range of 0.006 to $6.0 \%$ $(\mathrm{w} / \mathrm{w})$ ) inhibited motility and at high concentrations lead to the mortality of rat spermatozoa (Dasgupta et al. 1971). Motility responses to urea were found to be dose dependent. In the same study, exposure of rabbit ovum to low urea concentrations immediately caused this tissue to contract and darken. Higher concentrations (0.6 and $6.0 \%$ ) induced severe changes in ovum structure causing it to become solid and opaque. In vitro studies have also shown that urea can elicit detrimental effects on rabbit embryos (Duby and Trischler 1986, ref. Canfield et al. 1990) a finding consistent with in vivo studies of rat embryos (Saitoh and Takahashi 1977). In contrast, Williams et al. (1987), observed no physiological changes in bull spermatozoa, mouse spermatozoa or developing mouse embryos cultured with uterine flushings collected on d 1, 5 and 10 of the oestrus cycle of cows fed low and high CP diets (120 and $230 \mathrm{~g} / \mathrm{kg} \mathrm{DM}$, respectively). Studies in non-lactating cows in positive energy balance have also shown that ovarian follicular growth and embryonic survival were unaffected by large differences (123 vs. 274 g/ 


\section{AGRICULTURAL AND FOOD SCIENCE IN FINLAND}

\section{Shingfield, K.J. et al. Protein feeding and reproductive efficiency}

kg DM) in dietary CP concentration (GarciaBojalil et al. 1994). Carroll et al. (1988) observed a marked increase in the urea concentration of vaginal mucus from 2.9 to $7.5 \mathrm{mmol} / \mathrm{l}$ stimulated by an increase in dietary CP content of $70 \mathrm{~g} /$ $\mathrm{kg}$ DM. Despite these increases, no effects on calving to first oestrus, days to first service, days open or number of services per conception were observed.

Maintaining the environment within the uterine lumen is a major determinant of embryo viability during early pregnancy. Conditions within the uterine lumen are subject to cyclic changes as a result of modified endometrial secretion occurring under hormonal regulation or that induced by the presence of a viable blastocyst (McRae 1984). Feeding high levels of CP has been reported to decrease reproductive efficiency, without affecting oestrus (Kaim et al. 1983, Canfield et al. 1990), suggesting that declines in conception rate may be related to changes in uterine environment. Feeding diets of different $\mathrm{CP}$ content has been shown to alter uterine secretion of urea, magnesium, potassium, phosphorus and zinc (Jordan et al. 1983). Furthermore, the ionic composition of secretions in the reproductive tract is known to influence the viability of spermatozoa, ovum and zygote via direct effects on cell metabolism (Hurley and Mutch 1973, Hurley et al. 1976). Consequently, impairments of uterine physiology could potentially explain sub-optimal conception rates in cows fed excessive protein. This suggestion is tentatively supported by studies in non-lactating heifers demonstrating that increases in dietary CP concentrations from $155 \mathrm{~g} / \mathrm{kg} \mathrm{DM}$ to $218 \mathrm{~g} / \mathrm{kg} \mathrm{DM}$ had no affect on uterine $\mathrm{pH}$ at the onset of oestrus, but by $\mathrm{d} 7$ post-oestrus $\mathrm{pH}$ was decreased (Elrod and Butler 1993). Repeating the experiment with lactating cows also demonstrated that excess protein regardless of source or rumen degradability had no effect on blood, saliva, urine or intrauterine $\mathrm{pH}$ at oestrus, but by $7 \mathrm{~d}$ post-oestrus uterine $\mathrm{pH}$ was significantly lower in high-protein groups.

A more detailed investigation of uterine function has recently been made possible by devel- opment of an endometrial cell culture system allowing a $\mathrm{pH}$ gradient to be established between apical and basal cellular compartments (Gilbert et al. 1996). The $\mathrm{pH}$ gradient has been shown to be sensitive to the presence of progesterone and oestradiol, while inclusion of both hormones results in a suppression of prostaglandin $\mathrm{PGF}_{2} \alpha$ and $\mathrm{PGE}_{2}$ secretion. However, inclusion of urea caused a significant reduction in the efficacy of progesterone to maintain a $\mathrm{pH}$ gradient between apical and basal compartments and a significant increase in prostaglandin $\mathrm{PGF}_{2} \alpha$ and $\mathrm{PGE}_{2}$ secretion. Increases in prostaglandin $\mathrm{PGF}_{2} \alpha$ secretion are particularly significant due to their recognised antagonistic effects on embryo development (Mauer and Beier 1976) and survival (Schrick et al. 1993).

\section{Changes in endocrine function}

Progesterone is known to have a major impact on reproductive efficiency. Follicular maturation, passage of fertilised embryos into the uterus, uterine secretions and maintenance of uterine environment necessary for pregnancy are all under the hormonal control of progesterone (Smith 1986). It has been suggested that high local or systemic urea concentrations may depress the binding of luteinizing hormone to luteal receptors which would cause progesterone concentrations to fall and lead to depressions in reproductive performance (Jordan and Swanson 1979a, Jordan et al. 1983). Often high circulating concentrations of progesterone prior to insemination have been observed to be associated with higher conception rates (Folman et al. 1973, Erb et al. 1976, Fonseca et al. 1983) while other studies have not identified a positive influence of progesterone (Bulman and Lamming 1978, Carroll et al. 1988). Feeding high levels of protein have been reported to lower plasma progesterone concentrations (Jordan and Swanson 1979b, Carroll et al. 1988, Sonderman and Larson 1989). In contrast, alterations of plasma luteinizing hormone or progesterone profiles have not been identified following excessive 
Vol. 8 (1999): 365-392.

protein feeding to non-lactating cows (Blauwiekel et al. 1986) or beef cattle (Rusche et al. 1993). Discrepancies between these studies may be explained by variations in the extent of protein degradation in the rumen or differences in magnitude of negative energy balance. Recently, Garcia-Bojalil et al. (1998) demonstrated that both peak and accumulated plasma progesterone concentrations assessed during the first $50 \mathrm{~d}$ of lactation were significantly related to dietary rumen degradable protein content. Diets were formulated to provide similar amounts of CP (206 and $207 \mathrm{~g} / \mathrm{kg} \mathrm{DM}$ ) but different amounts of rumen degradable protein (111 and $157 \mathrm{~g} / \mathrm{kg} \mathrm{DM}$, respectively). Increases in daily dietary rumen degradable protein intake from 2.18 to $3.05 \mathrm{~kg}$ were associated with large differences in peak (18 and $26 \mu \mathrm{mol} / 1$, respectively) and accumulative progesterone concentrations (1.7 and 2.9 $\mathrm{mmol} / \mathrm{l}$, respectively). Responses were also associated with changes in dietary energy content achieved by inclusion $(22 \mathrm{~g} / \mathrm{kg} \mathrm{DM})$ of rumen protected fat. Inclusion of fat lead to increases in both peak (30 vs. $25 \mu \mathrm{mol} / \mathrm{l}$ ) and accumulative progesterone concentrations (2.7 vs. 1.9 $\mathrm{mmol} / \mathrm{l})$.

Over the course of three cycles during early lactation, plasma progesterone concentrations tend to increase, but the rate and extent of increase appears to be modified by the extent of negative energy balance (Villa-Godoy et al. 1988, Spicer et al. 1990). Energy deficiencies can lead to depressed conception rates (e.g. Parker and Blowey 1976, Youdan and King 1977), which may be attributed to reduced plasma progesterone concentrations due to a lowered sensitivity of luteal cells to luteinizing hormone (Apgar et al. 1975). Decreased plasma progesterone concentration during early lactation leading to compromised uterine function appears to be the most probable cause of impaired fertility in cows fed excessive protein. Relationships between reproductive efficiency and protein feeding may often be confounded by variations in energy status since both protein and energy supply appear to impinge on the hypothalamohypophyseal-ovarian axis, resulting in modified luteal production of progesterone (Ferguson and Chalupa 1989). Based on studies conducted with dairy cows there is little evidence to suggest that excessive protein feeding causes detrimental effects on follicular maturation, ovulation or fertilisation, but the most convincing experimental evidence suggests an associated reduction in embryo survival due to a sub-optimal uterine environment (Butler 1998).

\section{Associations between protein feeding and reproductive efficiency in Finland}

Data concerning the association between reproductive efficiency and protein feeding under Finnish production situations is limited. Reproductive studies in Finnish cows have tended to concentrate on the role of energy intake (Miettinen 1990a, 1991), feeding regimen (Heinonen et al. 1988, Miettinen 1990c) breed (Kuni and Pirinen, 1988) or parity (Miettinen 1990b) on reproductive efficiency.

In Finland, dairy cow rations contain only relatively moderate $\mathrm{CP}$ concentrations, typically 150 g/kg DM (Kaustell et al. 1998) suggesting that potential reproductive inefficiencies due to excessive protein feeding are likely to be minimised. Furthermore, Miettinen (1991) reported that the proportion of cows fed diets according to Finnish feeding standards with plasma urea concentrations lower than $150 \mathrm{mg} / \mathrm{l}$ at 14 and 60 d postpartum was 0.89 and 0.65 , respectively. Plasma urea concentrations of cows above this threshold had much higher conception rates (71\%) compared to cows with values below this concentration (52\%).

About $60 \%$ of Finnish dairy herds participate in a national milk recording scheme and account for approximately $73 \%$ of total milk production in Finland. In 1993, 20018 herds participated in this scheme. Recording was initiated when cows 


\section{Shingfield, K.J. et al. Protein feeding and reproductive efficiency}

Table 2. Summary of intake, production and reproductive efficiency data derived from 16051 Finnish dairy herds participating in the national recording scheme during 1993, used to examine the association between on-farm protein feeding and reproductive efficiency in Finnish dairy herds.

\begin{tabular}{|c|c|c|c|c|}
\hline & Mean & SD & Min & $\operatorname{Max}$ \\
\hline Number of cows per herd & 14 & 5.7 & 1 & 221 \\
\hline \multicolumn{5}{|c|}{ Milk production and composition } \\
\hline Milk yield (kg/cow per year) & 6719 & 936.6 & 2789 & 11853 \\
\hline Fat $(\mathrm{g} / \mathrm{kg})$ & 44.3 & 3.7 & 29.1 & 66.9 \\
\hline Protein $(\mathrm{g} / \mathrm{kg})$ & 32.8 & 1.1 & 28.6 & 39.9 \\
\hline Urea $(\mathrm{mg} / \mathrm{l})^{\dagger}$ & 250 & 46.3 & 15 & 432 \\
\hline \multicolumn{5}{|l|}{ Intake (/cow per year) } \\
\hline Dry matter $(\mathrm{kg})$ & 5679 & 658.2 & 3367 & 9041 \\
\hline Metabolisable energy (MJ) & 63321 & 7634 & 35685 & 106447 \\
\hline Crude protein $(\mathrm{kg})$ & 853 & 117.5 & 445 & 1986 \\
\hline \multicolumn{5}{|c|}{ Diet composition ( $\mathrm{g} / \mathrm{kg}$ dry matter) } \\
\hline Crude protein & 150 & 10.3 & 83 & 226 \\
\hline Forage & 670 & 67 & 250 & 910 \\
\hline Concentrate & 330 & 67 & 90 & 750 \\
\hline \multicolumn{5}{|l|}{ Reproductive efficiency } \\
\hline Calving interval (d) & 387 & 21.8 & 320 & 605 \\
\hline First service interval (d) & 80 & 14.1 & 23 & 189 \\
\hline Inseminations per calving & 1.7 & 0.38 & 1 & 5 \\
\hline
\end{tabular}

${ }^{\dagger}$ Determined in 6731 recorded herds

were turned out to pasture during May 1993 and was continued to the end of the indoor housing period the following year. Milk production of recorded herds was measured monthly and milk fat, protein, lactose and urea content were determined bimonthly (Karjantarkkailutulokset 1993). On-farm consumption of feeds was estimated based on assessments of feed stores in the autumn, and was reported in the beginning, middle and at the end of the indoor housing period. The contribution of grazed grass was estimated as the difference between annual energy requirements predicted according to milk production and recorded consumption during the indoor housing period. Total consumption of feeds by dairy cows fed according to Finnish feeding standards adopted in 1993 (Salo et al. 1990) was divided by the number of cows in a herd to give an estimate of the mean annual intake of dairy cows within a herd. More detailed information concerning feed evaluation and sampling procedures used to obtain this data are documented by Kaustell et al. (1998). Based on the criteria that records of milk composition, feed consumption and reproductive parameters of recorded herds should be complete, associations between on-farm protein feeding and reproductive efficiency were examined using measurements from 16051 herds (refer to Table 2).

Use of field data to assess associations between on-farm protein feeding and reproductive efficiency is subject to criticism, because autocorrelation between nutritional parameters and confounding effects due to standard feeding policies are not completely taken into account. Effects due to cow age (Ferguson and Chalupa 1989) or reproduction management (Barton et al. 1996) will also introduce additional bias, since failure to detect oestrus for example has been suggested to be the main reason for extended calving intervals (Whitmore 1984). Accounting for differences in on-farm management is particularly problematic, because highly productive herds are likely to operate under the most 
Fig. 2. Influence of dietary crude protein content on annual milk production of Finnish milk recorded herds during $1993(n=16051)$ based on classification according to dietary crude protein content. Each point represents mean $( \pm \mathrm{SE})$ of herds in each class and the dotted line indicates the mean of all recorded herds.
Vol. 8 (1999): 365-392.

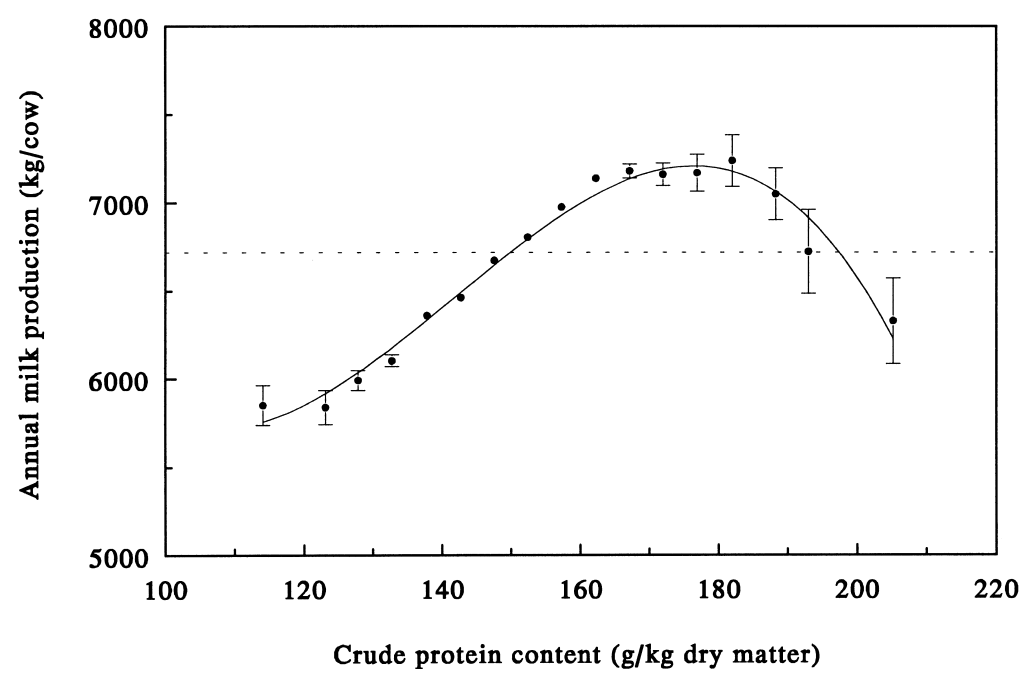

effective management regimens. Furthermore, assessment of protein feeding based entirely on dietary $\mathrm{CP}$ content does not account for variations in rumen degradable protein intake. Accepting these criticisms and a lack of alternative data, evaluation of field data was conducted by classing measurements of nutrient intake, milk production and reproductive efficiency according to dietary CP content. Classification was performed over the entire range of dietary $\mathrm{CP}$ concentrations in increments of $5 \mathrm{~g} \mathrm{CP} / \mathrm{kg} \mathrm{DM}$, generating 17 protein classes. Use of mean values of each protein class (range 114-205 g/kg DM) indicated that annual milk production was closely related to dietary CP content (Fig. 2). Based on this relationship, optimal milk production was associated with feeding diets containing between 160 and $180 \mathrm{~g} \mathrm{CP} / \mathrm{kg}$ DM. However, marginal milk yield responses to increases in dietary CP content between $170-180 \mathrm{~g} / \mathrm{kg}$ DM are unlikely to be sufficient to cover additional feeding costs.

Use of the same approach tended to indicate that reproductive parameters were optimised at different dietary CP contents necessary for highest milk production (Fig. 3). Measures of reproductive efficiency, i.e. calving interval, first service interval and number services per calving ap- peared to be most efficient in herds fed diets containing between 155-160, 165-170 and 130$135 \mathrm{~g} \mathrm{CP} / \mathrm{kg} \mathrm{DM}$, respectively. Feeding diets containing insufficient or excessive protein tended to result in an extended calving interval, a prolonged first service interval and an increase in the number of services per calving. The extent of reproductive inefficiency appeared to be marginally greater for herds fed low compared to high levels of dietary protein. In herds ( $\mathrm{n}=$ 151) fed diets containing less than $125 \mathrm{~g} \mathrm{CP} / \mathrm{kg}$ $\mathrm{DM}$, calving interval, first service interval and number of services per calving were on average 394, 84 and 1.73, respectively. Mean calving interval, first service interval and number of services per calving were 392,80 and 1.84 , respectively in herds $(n=21)$ fed diets containing levels of CP in excess of $190 \mathrm{~g} / \mathrm{kg}$ DM.

Due to high concentrate costs and a shortage of home grown protein supplements, Finnish milk production has been reliant on feeding high quality forages. During 1993, protein evaluation in Finland was based on digestible crude protein (ARC 1965, Salo et al. 1990) which coupled with restrictions in the availability of protein supplements lead to the use of increased nitrogen fertiliser application to increase grass $\mathrm{CP}$ content. Due to rapid and extensive degradation 
Shingfield, K.J. et al. Protein feeding and reproductive efficiency
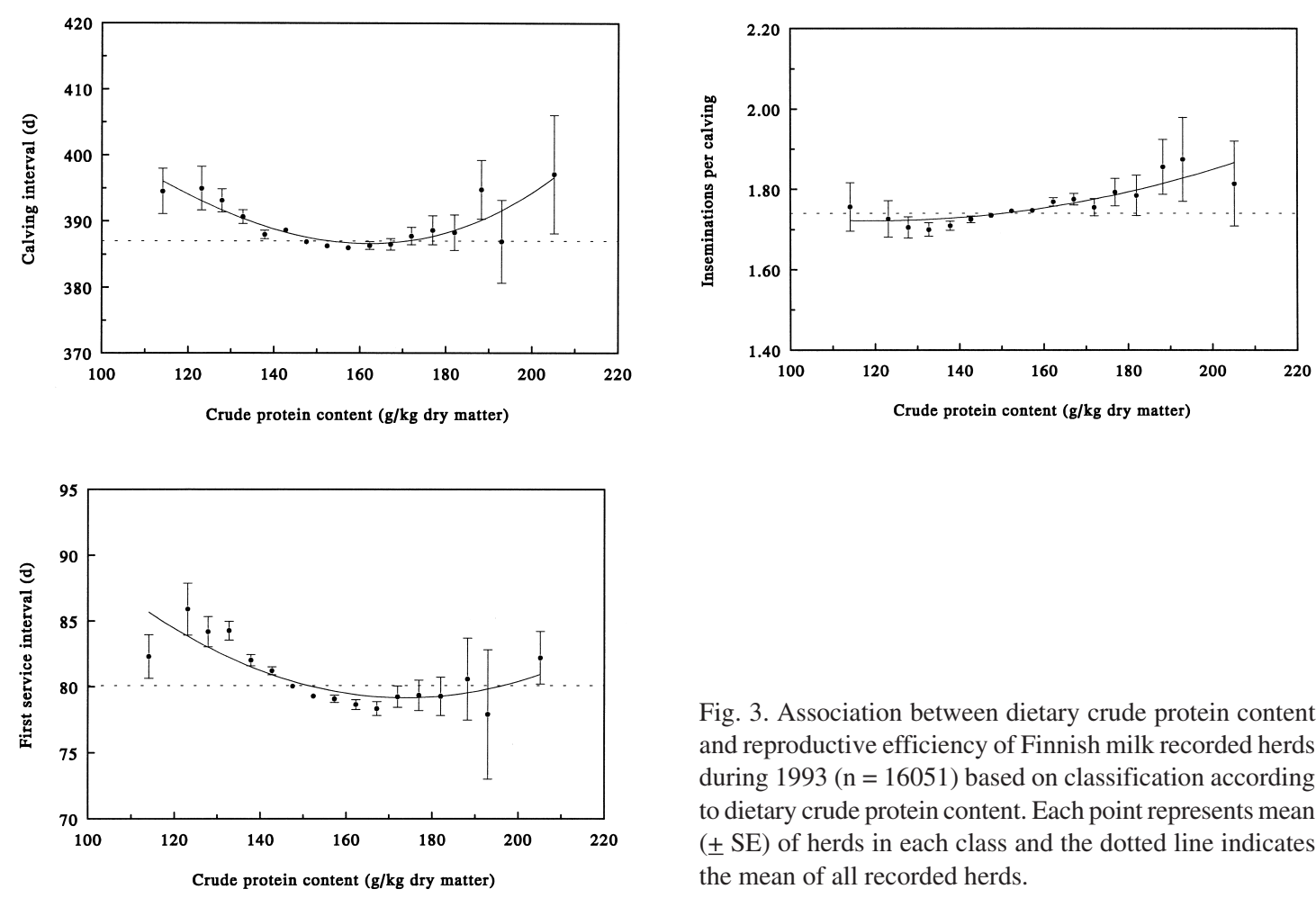

Fig. 3. Association between dietary crude protein content and reproductive efficiency of Finnish milk recorded herds during $1993(\mathrm{n}=16051)$ based on classification according to dietary crude protein content. Each point represents mean $( \pm S E)$ of herds in each class and the dotted line indicates the mean of all recorded herds.

of silage protein (Huhtanen 1998a), a close relationship between silage CP content and reproductive efficiency of Finnish herds may be expected. Examination of data from recorded herds tended to indicate that associations between reproductive efficiency and silage $\mathrm{CP}$ content were consistent with and only marginally better than that based on dietary CP content (data not presented).

Examination of field data indicated that implementation of on-farm feeding strategies to increase dietary CP content to approximately 170 $\mathrm{g} / \mathrm{kg}$ DM would lead to improved milk production equivalent to $500 \mathrm{~kg} / \mathrm{cow}$ per year. Reproductive efficiency of recorded herds fed diets containing $150 \mathrm{~g} \mathrm{CP} / \mathrm{kg}$ DM was defined by a mean $387 \mathrm{~d}$ calving interval, $80 \mathrm{~d}$ first service interval and 1.74 inseminations per calving. Corresponding values in herds fed diets containing $170 \mathrm{~g} \mathrm{CP} / \mathrm{kg} \mathrm{DM}$ were 387, 79 and 1.77, re-

spectively. If the limitations of field data and the lack of rigorous statistical evaluation are accepted, measurements derived from Finnish recorded herds tentatively supports the suggestion that increases in dietary CP content from 150 to 170 $\mathrm{g} / \mathrm{kg}$ DM would not impose large constraints on reproductive efficiency.

\section{Monitoring on-farm protein feeding}

Due to variations in chemical composition of feed ingredients and errors inherent in all protein evaluation systems, inaccuracies in dairy cow protein feeding can occur, which can lead to an inefficient utilisation of dietary protein. It 
Vol. 8 (1999): 365-392.

is well established that measurements of urea concentrations in blood often reflect the efficiency of utilisation of dietary CP (e.g. Lewis 1957). Numerous studies have been conducted over the last two decades to assess the potential of urea concentrations in blood or milk as a diagnostic test of $\mathrm{N}$ utilisation in the dairy cow (refer to DePeters and Ferguson 1992, Shingfield et al. 1997). Recent evaluations have demonstrated that urea concentrations in milk are closely related to the proportion of dietary protein degraded in the rumen (Schepers and Meijer 1998), the ratio of dietary $\mathrm{CP}$ to energy intake or dietary CP content (Broderick and Clayton 1997, Hof et al. 1997). Examination of data derived from 18 Finnish production trials has also indicated that the ratio of $\mathrm{CP}$ to energy intake is the major nutritional factor affecting the urea concentration in milk (Shingfield and Huhtanen 1998).

\section{Associations between urea concentrations in blood and milk with reproductive efficiency}

\section{Plasma urea concentration}

A number of reproductive studies have documented an association between plasma urea concentration (PUC) and reproductive performance. Kaim et al. (1983) reported that pregnancy rates were lower in cows with a PUC of $360 \mathrm{mg} / \mathrm{l} \mathrm{com-}$ pared to cows with a PUC of $193 \mathrm{mg} / \mathrm{l}$. A urea concentration in blood exceeding $429 \mathrm{mg} / \mathrm{l}$ has also been reported to be associated with reduced conception rates (Ferguson et al. 1988, 1993). Collection of blood samples from 160 cows on the day of insemination indicated that protein feeding regimens leading to PUC values above $407 \mathrm{mg} / \mathrm{l}$ were associated with a 20 percentage point decrease in pregnancy rate (Butler et al. 1996).
In order to examine associations between PUC and reproductive efficiency assessed as conception rate, data from 10 published studies were compared. Measurements of urea reported in whole blood were recalculated as their concentration in plasma according to Broderick and Clayton $(1997)$ where PUC $(\mathrm{mg} / \mathrm{l})=1.021 \mathrm{x}$ urea concentration in whole blood $(\mathrm{mg} / \mathrm{l})+8.55(\mathrm{n}=$ $\left.226, \mathrm{r}^{2}=0.918\right)$. Increases in PUC were associated with depressions in conception rate in several, but not in all cases (Fig. 4). In some studies increases in PUC elicited positive conception rate responses (Miettinen 1991, Barton et al. 1996). Discrepancies between conception rate responses to variations in PUC may be related to between-study differences in experimental and management factors or blood sampling protocols, since PUC is subject to considerable diurnal variation (Miettinen and Juvonen 1990, Gustafsson and Palmquist 1993). In conclusion, examination of data from 10 studies does not provide convincing evidence to support suggestions that measurements of PUC would be beneficial in maintaining or improving on-farm reproductive efficiency. Furthermore, implementation of a strict reproductive management regimen has been shown to result in high reproductive efficiencies irrespective of PUC (Barton et al. 1996).

\section{Milk urea concentration}

In contrast to blood, milk is regarded as a more ideal test medium since it is collected quantitatively, easily sampled (Giesecke et al. 1994) and routinely measured on a large scale in many European countries as part of a national milk recording scheme (Emanuelson et al. 1989). Milk urea concentrations (MUC) appear to be directly related to concentrations in plasma (e.g. Butler et al. 1996, Metcalf et al. 1996) and therefore several studies have assessed the incidence of reproductive inefficiencies in relation to MUC. Based on an evaluation of reproduction records of 915 German cows, Wenninger and Distl (1994) reported that significant curvilinear relationships existed between MUC with days 
Shingfield, K.J. et al. Protein feeding and reproductive efficiency

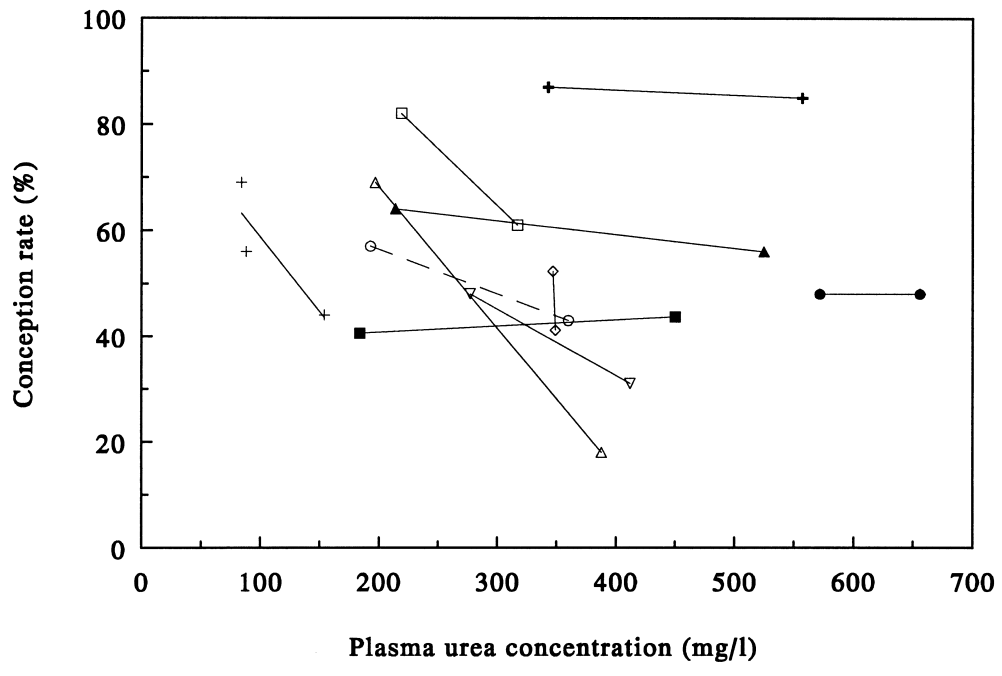

Fig. 4. Association between plasma urea concentration and conception rate reported in the literature. Data derived from Folman et al. 1981 (+), Piatkowski et al. 1981 $(\triangle)$, Kaim et al. 1983 (o), Howard et al. 1987 (+), Carroll et al. 1988 (ム), Bruckental et al. 1989 $(\bullet)$, Canfield et al. $1989(\nabla)$, Pehrson et al. $1992(\diamond)$, Elrod and Butler $1993(\square)$ and Barton et al. 1996 (ם). open, inseminations per service, conception rate at first service and the incidence of metritis. Based on this data, reproductive traits appeared to be optimised in cows with a MUC of between 150 and $250 \mathrm{mg} / \mathrm{l}$. Sato et al. (1996) reported that cows with MUC in excess of $386 \mathrm{mg} / \mathrm{l}$ at the time of insemination failed to become pregnant. However, these findings were not confirmed by measurements in the subsequent year of the study. Gustafsson and Carlsson (1993) reported that intervals between calving and first (mean 82 d) and last (mean $108 \mathrm{~d}$ ) services were delayed in herds with low or high bulk tank MUC. Calving to last service intervals were found to be much shorter in herds with a mean MUC between 270 and $300 \mathrm{mg} / \mathrm{l}$. These findings are consistent with studies which have identified reproductive inefficiencies in cows with either low (Pehrson et al. 1992, Carlsson and Pehrson 1993) or high MUC (Carroll et al. 1988, Ferguson et al. 1988, Canfield et al. 1990, Pehrson et al. 1992, Butler et al. 1996). The association between MUC and reproductive efficiency has often been described by non-linear relationships indicating optimal reproduction efficiency at concentrations between 150-250 (Wenninger and Distl 1994), 240-410 (Pehrson et al. 1992) and 270-300 mg/l (Gustafsson and Carlsson 1993).
Over the last 10 years, urea concentrations of bulk tank milk have been routinely measured to monitor protein feeding on Finnish dairy farms. Concentrations of urea in milk between 200 and $300 \mathrm{mg} / \mathrm{l}$ have been used to describe an efficient utilisation of dietary protein. On-farm protein feeding regimens resulting in bulk tank MUC within these limits are considered to be optimal with respect to both reproductive efficiency and milk production. During the last couple of years the proportion of Finnish bulk tank milk samples with urea concentrations determined using an enzymatic method (Rajamäki and Rauramaa 1984) above $300 \mathrm{mg} / \mathrm{l}$ has markedly increased (Table 3). Data from Sweden has also indicated that MUC of samples collected from individual cows were on average $300 \mathrm{mg} / \mathrm{l}$ between October 1996 and July 1997, and that 39\% of samples from 51-111 d postpartum cows had concentrations in excess of $324 \mathrm{mg} / \mathrm{l}$ (Eriksson and Gustafsson 1998).

Since the implementation of routine measurements, MUC recommendations have remained unchanged, despite annual milk production increases of approximately $100 \mathrm{~kg}$ per cow over the last decade (Nousiainen 1997). It has recently been suggested that in order to realise potential improvements in milk production the range of MUC used for advisory purposes should 
Vol. 8 (1999): 365-392.

Table 3. Urea concentrations of bulk tank milk in Finland between 1988 and 1999.

\begin{tabular}{|c|c|c|c|c|c|}
\hline \multirow{3}{*}{$\begin{array}{l}\text { Indoor housing } \\
\text { Period }\end{array}$} & \multirow{3}{*}{$\begin{array}{l}\text { Sample } \\
\text { number }\end{array}$} & \multicolumn{4}{|c|}{ Milk urea concentration $(\mathrm{mg} / \mathrm{l})^{\dagger}$} \\
\hline & & \multirow{2}{*}{$\begin{array}{l}\text { Mean } \\
(\mathrm{SD})\end{array}$} & \multicolumn{3}{|c|}{ Proportion of samples } \\
\hline & & & $<200$ & $200-300$ & $>300$ \\
\hline $1988-91^{1}$ & 240000 & ND & 0.22 & 0.63 & 0.15 \\
\hline $1990-91^{1}$ & 51000 & ND & 0.14 & 0.61 & 0.26 \\
\hline $1991-92^{1}$ & 86000 & ND & 0.14 & 0.52 & 0.34 \\
\hline $1992-93^{1}$ & 95000 & ND & 0.29 & 0.55 & 0.17 \\
\hline $1993-94^{1}$ & 93000 & $249(74)$ & 0.25 & 0.52 & 0.23 \\
\hline $1994-95^{1}$ & 86334 & $266(77)$ & 0.19 & 0.48 & 0.33 \\
\hline $1995-96^{1}$ & 140203 & $252(82)$ & 0.21 & 0.43 & 0.35 \\
\hline $1996-97^{2}$ & 142496 & $243(77)$ & 0.28 & 0.48 & 0.24 \\
\hline $1997-98^{2}$ & 149424 & $300(77)$ & 0.09 & 0.38 & 0.52 \\
\hline $1998-99^{3}$ & 87968 & $294(86)$ & 0.14 & 0.37 & 0.49 \\
\hline
\end{tabular}

ND: Not determined

† Determined according to Rajamäki and Rauramaa (1984)

${ }^{1}$ Derived from Nousiainen (1997)

${ }^{2}$ Derived from Tommila and Jokela (unpublished data)

${ }^{3}$ Derived from Nousiainen (unpublished data)

be modified to $200-350 \mathrm{mg} / \mathrm{l}$ (Shingfield et al. 1997, Shingfield and Jokela 1998), but the potential impact of these changes on reproductive efficiency is unclear.

Despite the large number of Finnish herds $(\mathrm{n}=20018)$ participating in the national milk recording scheme, MUC measurements of bulk tank were conducted for only 6731 herds. Of these, 566 herds had less than 3 measurements performed during the entire recording period. Based on the criteria that estimates of the average annual urea concentration in bulk tank milk should be based on the mean of a minimum of 6 bimonthly assessments, records of 5437 herds were used to assess the association between MUC and the reproductive efficiency under Finnish conditions. Milk production, reproductive efficiency and MUC data derived from these recorded herds is summarised in Table 4. Recording data was evaluated by classifying herds according to the mean annual MUC in increments of $20 \mathrm{mg} / \mathrm{l}$, generating $17 \mathrm{MUC}$ classes. Classes that contained less than 14 herds, proportionately 0.0025 of sample population were considered to be unreliable. Con- sequently, evaluation was conducted using 14 classes over a range of bulk tank MUC between 152 and $368 \mathrm{mg} / \mathrm{l}$. Based on this approach, annual milk production was observed to highest in herds with a mean annual bulk tank MUC of $308 \mathrm{mg} / \mathrm{l}$ (Fig. 5). In contrast, associations between bulk tank and reproductive performance of Finnish herds were less well defined. Increases in bulk tank MUC from 200 to $300 \mathrm{mg} / \mathrm{l}$ in Finnish herds was associated with only minor differences in calving interval (Fig. 6), a $2 \mathrm{~d}$ reduction in the first service interval (data not presented) and an increase (0.05) in the number of inseminations per calving (Fig. 7). Finnish herds $(n=4268)$ with an estimated mean annual bulk tank MUC within the range recommended in 1993 (200-300 $\mathrm{mg} / \mathrm{l})$ had calving and first intervals of $387( \pm 2.5)$ and $80( \pm 2.0) \mathrm{d}$, respectively and required $1.7( \pm 0.06)$ inseminations per calving. Mean calving intervals, first service intervals and number of services per calving of herds $(n=616)$ with bulk tank MUC between 300 and $350 \mathrm{mg} / \mathrm{l}$ were $388( \pm 1.8) \mathrm{d}$, $81( \pm 2.1) \mathrm{d}$ and $1.7( \pm 0.09)$, respectively. Corresponding values for herds $(n=503)$ with an- 


\section{Shingfield, K.J. et al. Protein feeding and reproductive efficiency}

Table 4. Summary of intake, production and reproductive efficiency data derived from 5437 Finnish dairy herds participating in the national recording scheme during 1993, used to examine the association between mean annual urea concentration in bulk tank milk and reproductive efficiency in Finnish dairy herds.

\begin{tabular}{lcccc}
\hline & Mean & SD & Min & Max \\
\hline Number of cows per herd & 14 & 5.2 & 2 & 104 \\
Milk production and composition & & & & \\
Milk yield (kg/cow per year) & 6735 & 935.5 & 3491 & 11136 \\
Fat (g/kg) & 44.4 & 3.8 & 29.5 & 66.9 \\
Protein (g/kg) & 32.8 & 1.1 & 28.6 & 37.5 \\
Urea (mg/l) & 254 & 40.7 & 82 & 411 \\
Intake (/cow per year) & & & & \\
Dry matter (kg) & 5647 & 665.0 & 3386 & 9041 \\
Metabolisable energy (MJ) & & & & \\
Crude protein (kg) & 856 & 115.5 & 448 & 1703 \\
Diet composition (g/kg dry matter) & 152 & 9.6 & 115 & 214 \\
Crude protein & 666 & 67 & 253 & 888 \\
Forage & 334 & 67 & 112 & 747 \\
Concentrate & & & & \\
Reproductive efficiency & 386 & 21.2 & 333 & 605 \\
Calving interval (d) & 79 & 13.9 & 42 & 189 \\
First service interval (d) & 1.7 & 0.37 & 1 & 4.2 \\
Inseminations per calving & & &
\end{tabular}

nual bulk tank MUC below $200 \mathrm{mg} / 1$ were 386 $( \pm 5.0) \mathrm{d}, 83( \pm 2.3) \mathrm{d}$ and $1.7( \pm 0.10)$, respectively.

The means and associated standard deviations for these reproductive parameters were re- markably similar between herds with mean annual urea concentrations in bulk tank MUC of below $200 \mathrm{mg} / \mathrm{l}$, between 200 and $300 \mathrm{mg} / \mathrm{l}$ and above $300 \mathrm{mg} / \mathrm{l}$. These findings tentatively suggest no consistent relationship between on-farm

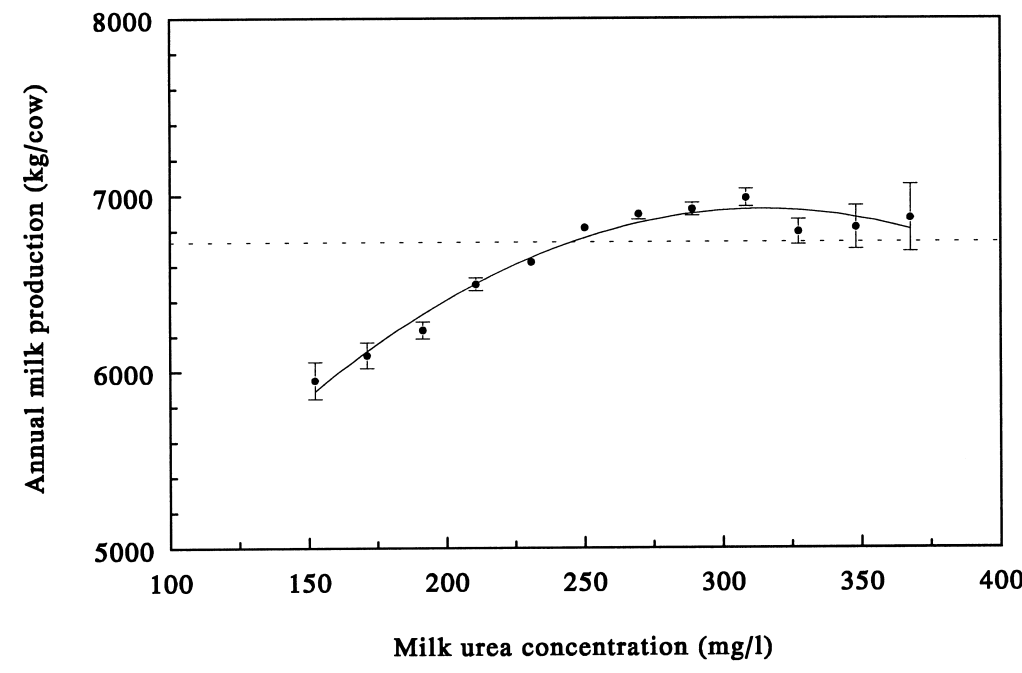

Fig. 5. Relationship between urea concentrations in bulk tank milk and annual milk production of Finnish milk recorded herds $(\mathrm{n}=$ 5437 ) during 1993 based on classification according to milk urea concentration. Each point represents mean $( \pm S E)$ of herds in each class and the dotted line indicates the mean of all recorded herds. 
Vol. 8 (1999): 365-392.

Fig. 6. Relationship between urea concentrations in bulk tank milk and calving interval of Finnish milk recorded herds during 1993 ( $n=5437$ ) based on classification according to milk urea concentration. Each point represents mean $( \pm \mathrm{SE})$ of herds in each class and the dotted line indicates the mean of all recorded herds.

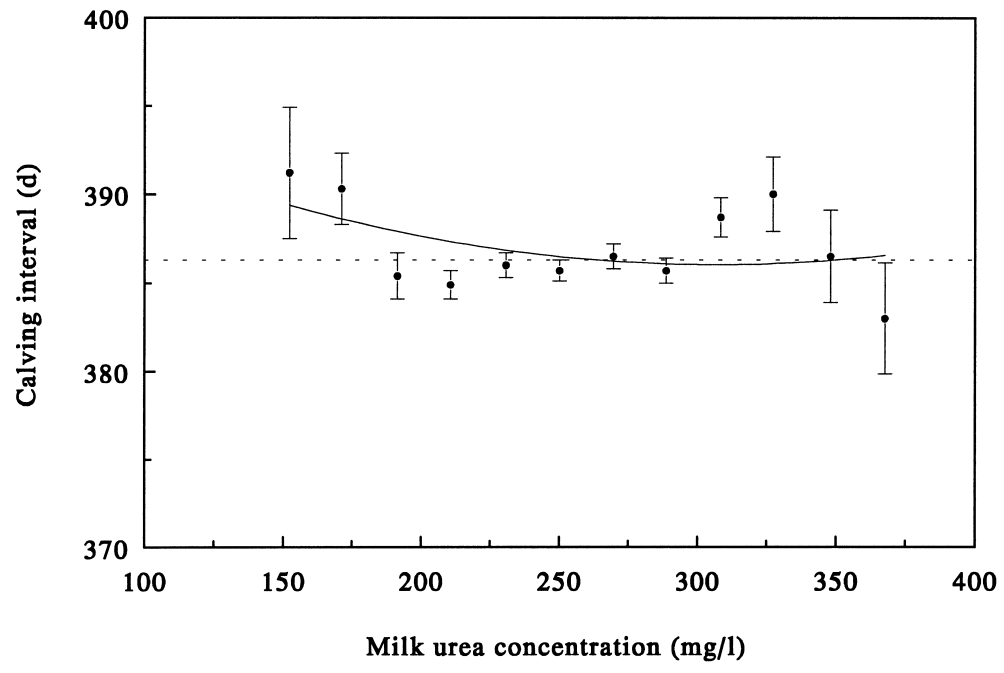

reproductive efficiency and mean annual bulk tank MUC. Notwithstanding the use of data collected from relatively large sample population ( $\mathrm{n}=5437$ herds) and MUC being determined on a minimum of 6 occasions, these findings are equivocal, since the effects due to standard feeding policies, cow age or reproduction management are confounded. Use of estimates of the mean annual bulk tank MUC of Finnish herds is also subject to criticism since it hides the true variation in MUC due to factors such as stage of lactation (e.g. Emanuelson et al. 1993, Carlsson et al. 1995). Furthermore, measurements of MUC in bulk tank reflect the average MUC of an individual herd (Refsdal 1983, Carlsson et al. 1995) and therefore represent an integrated mean of MUC from both pregnant and non-pregnant animals. In a similar evaluation based on measurements collected from 256 herds in Norway, differences in herd geographical location were iden-
Fig. 7. Relationship between urea concentrations in bulk tank milk and number of inseminations per calving of Finnish milk recorded herds during 1993 ( $\mathrm{n}=5$ 437) based on classification according to milk urea concentration. Each point represents mean $( \pm S E)$ of herds in each class and the dotted line indicates the mean of all recorded herds.

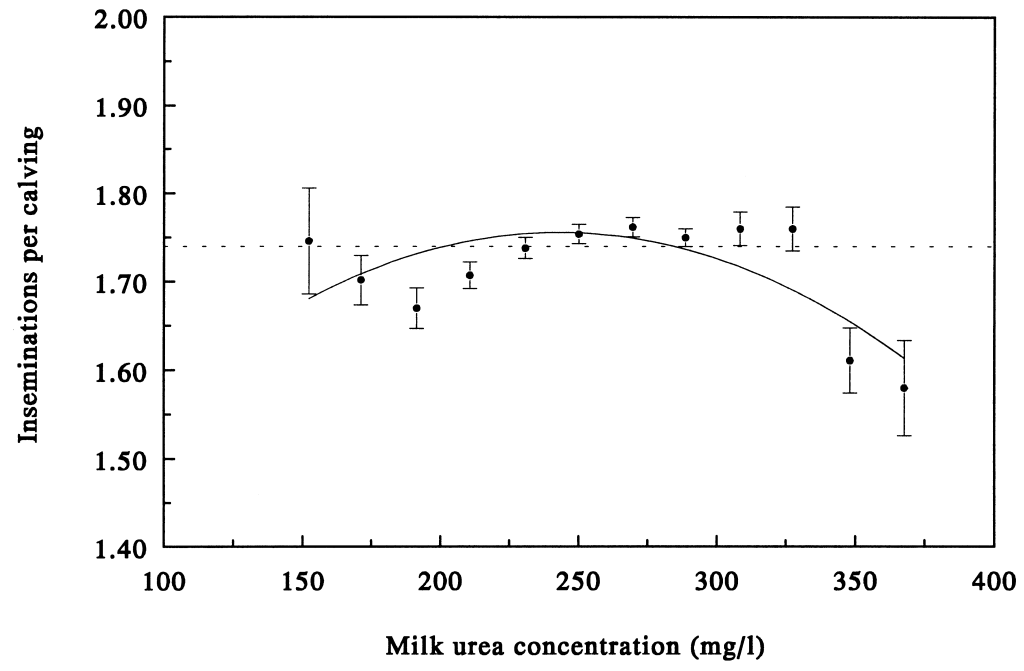


Shingfield, K.J. et al. Protein feeding and reproductive efficiency

tified as an important limitation to the use of bulk tank MUC as a diagnostic of protein feeding with respect to reproductive efficiency (Ropstad and Refsdal 1987).

Despite these criticisms and a distinct lack of alternative information, examination of recording data collected during 1993 tended to indicate that implementation of recommended urea concentrations in bulk tank milk of between 200 and $350 \mathrm{mg} / \mathrm{l}$ would not impose large constraints on the reproductive efficiency of Finnish dairy herds. Comparison of the reproductive efficiency of recorded herds with mean annual bulk tank urea concentrations within the range of $200-300 \mathrm{mg} / \mathrm{l}$ and $300-350 \mathrm{mg} / \mathrm{l}$, indicated that increases in MUC may be associated with on average, a $3 \mathrm{~d}$ extension of calving and first service intervals. It is however impossible from evaluation of field data to accurately predict the magnitude of reproductive responses to changes in bulk tank MUC for an individual herd.

\section{Conclusions}

Reproductive responses of dairy cows to increases in dietary CP concentrations tend to be inconsistent. Most, but not all studies have reported a negative association between reproductive performance and increased protein feeding. Dis- crepancies in reproductive responses may arise due to between-study differences in experimental design, uterine health, cow age, parity, nutrient intake, reproductive management or the size of sample populations. Detrimental effects on reproductive efficiency attributed to excess protein feeding often appear to be more clearly associated with either an excessive intake of rumen degradable or undegradable protein and the extent of postpartum negative energy balance. The most convincing experimental evidence suggests that detrimental effects associated with excessive protein feeding appear to be mediated by increased concentrations of urea in peripheral blood leading to compromised uterine function.

Evaluation of data collected from Finnish herds participating in the National milk recording scheme during 1993, indicated that feeding diets containing between 170 and $180 \mathrm{~g} \mathrm{CP} / \mathrm{kg}$ DM resulted in optimal milk production. Furthermore, comparison of herds feeding diets containing between 140 and $180 \mathrm{~g} \mathrm{CP} / \mathrm{kg} \mathrm{DM}$, suggested that increased on-farm protein feeding is not consistently associated with compromised reproductive efficiency. Based on this data, it is concluded that increasing the CP content of Finnish dairy cow rations from 150 to between 170 and $180 \mathrm{~g} / \mathrm{kg}$ DM could potentially allow improvements in milk production to be realised without leading to significant reductions in reproductive efficiency.

\section{References}

Adashi, E.Y., Hsueh, A.J.W. \& Yen, S.S.C. 1981. Insulin enhancement of luteinizing hormone and follicle stimulating hormone released by cultured pituitary cells. Endocrinology 108: 1441-1449.

Agricultural and Food Research Council 1992. Technical Committee on Responses to Nutrients, report number 9. Nutritive requirements of ruminant animals: Protein. Nutrition, Abstracts and Reviews (Series B) 62: 788-835.

Apgar, J., Aspros, D., Hixon, J.E., Saatman, R.R. \& Hansel, W. 1975. Effect of restricted feed intake on the sensitivity of the bovine corpus luteum to $\mathrm{LH}$ in vitro. Journal of Animal Science 41: 1120-1123.

ARC 1965. The Nutrient Requirements of Farm Livestock, No. 2 Ruminants. Technical Review by an Agricultural Research Council Working Party, HMSO. 264 p.

Bartley, E.E., Avery, T.B., Nagaraja, T.G., Watt, B.R., Davidovich, A., Galitzer, S. \& Lassman, B. 1981. Ammonia toxicity in cattle. V. Ammonia concentration of lymph and portal, carotid and jugular blood after ingestion of urea. Journal of Animal Science 53: 494-498. 
Vol. 8 (1999): 365-392.

Barton, B.A., Rosario, H.A., Anderson, G.W., Grindle, B.P. \& Carroll, D.J. 1996. Effects of dietary crude protein, breed, parity and health status on the fertility of dairy cows. Journal of Dairy Science 79: 2225-2236.

Bishonga, C., Robinson, J.J., McEvoy, T.G., Aitken, R.P., Findlay, P.A. \& Robertson, I. 1994. The effects of rumen degradable protein in ewes on ovulation rate, fertilisation and embryo survival in vivo and during in vitro culture. Animal Production 58: 81A (Abstract).

Blanchard, T., Ferguson, J., Love, L., Takeda, T., Henderson, B., Hasler, J. \& Chalupa, W. 1990. Effect of dietary crude protein type on fertilization and embryo quality in dairy cattle. American Journal of Veterinary Research 51: 905-908.

Blauwiekel, R., Kincaid, R.L. \& Reeves, J.J. 1986. Effect of high crude protein on pituitary and ovarian function in Holstein cows. Journal of Dairy Science 69: 439-446.

Bodeker, D., Winkler, A. \& Holler, H. 1990. Ammonia absorption from the isolated reticulo-rumen of sheep. Experimental Physiology 75: 587-595.

Brockman, R.P. \& Laarveld, B. 1986. Hormonal regulation of metabolism in ruminants: A review. Livestock Production Science 14: 313-334.

Broderick, G.A. \& Clayton, M.K. 1997. A statistical evaluation of animal and nutritional factors influencing concentrations of milk urea nitrogen. Journal of Dairy Science 80: 2964-2971.

- \& Merchen, N.R. 1992. Markers for quantifying microbial protein synthesis in the rumen. Journal of Dairy Science 75: 2618-2632.

Bruckental, I., Drori, D., Kaim, H.L. \& Folman, Y. 1989. Effects of source and level of protein on milk yield and reproductive performance of high-producing primiparous and multiparous dairy cows. Animal Production 48: 319-329.

Bulman, D.C. \& Lamming, G.E. 1978. Milk progesterone levels in relation to conception, repeat breeding and factors influencing acyclicity in dairy cows. Journal of Reproduction and Fertility 54: 447-458.

Butler-Hogg, B.W., Wood, J.D. \& Bines, J.A. 1985. Fat partitioning in British Friesian cows: the influence of physiological state on dissected body composition. Journal of Agricultural Science, Cambridge 104: 519528.

Butler, W.R. 1998. Review: Effect of protein nutrition on ovarian and uterine physiology in dairy cattle. Journal of Dairy Science 81: 2533-2539.

- , Calaman, J.J. \& Beam, S.W. 1996. Plasma and milk urea nitrogen in relation to pregnancy rate in lactating dairy cattle. Journal of Animal Science 74: 858865.

- \& Elrod, C.C. 1991. Nutrition and reproduction relationships in dairy cattle. Proceedings of the Cornell Nutrition Conference for Feed Manufacturers. Ithaca, NY. p. 73-82.

-, Everett, R.W. \& Coppock, C.E. 1981. The relationship between energy balance, milk production and ovulation in postpartum Holstein cows. Journal of Animal Science 53: 742-748.

- \& Smith, R.D. 1989. Interrelationships between energy balance and postpartum reproductive function in dairy cattle. Journal of Dairy Science 72: 767-783. Canfield, R.W., Sniffen, C.J. \& Butler, W.R. 1990. Effects of excess degradable protein on postpartum reproduction and energy balance in dairy cattle. Journal of Dairy Science 73: 2342-2349.

Carlsson, J. \& Pehrson, B. 1993. The relationships between seasonal variations in the concentration of urea in bulk milk and the production and fertility of dairy herds. Journal of Veterinary Medicine Series A 40: 205-212.

- , Bergström, J. \& Pehrson, B. 1995. Variations with breed, age season, yield, stage of lactation and herd in the concentration of urea in bulk milk and individual cow's milk. Acta Veterinaria Scandinavica 36: 245-254.

Carroll, D.J., Barton, B.A., Anderson, G.W. \& Smith, R.D. 1988. Influence of protein intake and feeding strategy on reproductive performance of dairy cows. Journal of Dairy Science 71: 3470-3481.

Chalmers, M.I., Grant, I. \& White, F. 1976. Nitrogen passage through the wall of the ruminant digestive tract. In: Cole, D.J.A. et al. (eds.). Protein Metabolism and Nutrition. Butterworths, London. p. 159-179.

Chalupa, W. 1984. Discussion of protein symposium. Journal of Dairy Science 67: 1134-1146.

Chamberlain, D.G. \& Choung, J.J. 1995. The importance of rate of ruminal fermentation of energy sources in diets for dairy cows. In: Garnsworthy, P.C. \& Cole, D.J.A. (eds.). Recent Advances in Animal Nutrition. Nottingham University Press, Nottingham. p. 3-27.

- , Martin, P.A. \& Robertson, S. 1989. Optimizing compound feed use in dairy cows with high intakes of silage. In: Haresign, W. \& Cole, D.J.A. (eds.). Recent Advances in Animal Nutrition. Butterworths, London. p. 175-193.

-, Thomas, P.C. \& Quig, J. 1986. Utilization of silage nitrogen in sheep and cows: amino acid composition of duodenal digesta and rumen microbes. Grass and Forage Science 41: 31-38.

Chandler, P.T., Brown, C.A., Johnston, R.P., Macleod, G.K., McCarthy, R.D., Moss, B.R., Rakes, A.H. \& Satter, L.D. 1976. Protein and methionine hydroxy analog for lactating cows. Journal of Dairy Science 59: 1897-1909.

Choung, J.J., Chamberlain, D.G., Thomas, P.C. \& Bradbury, I. 1990. The effects of intraruminal infusions of urea on the voluntary intake and milk production of cows receiving grass silage diets. Journal of Dairy Research 57: 455-464.

Cottrill, B.R. 1993. Characterisation of nitrogen in ruminant feeds. In: Garnsworthy, P.C. \& Cole, D.J.A. (eds.). Recent Advances in Animal Nutrition. Nottingham University Press, Nottingham. p. 39-53.

Czerkawski, J.W. 1986. An Introduction to Rumen Studies. Pergamon Press Limited, Oxford. $236 \mathrm{p}$.

Dasgupta, P.R., Kar, A.B. \& Dahr, M.L. 1971. Spermicidal activity of urea. Indian Journal of Experimental Biology 9: 414-415.

DePeters, E.J. \& Ferguson, J.D. 1992. Nonprotein nitrogen and protein distribution in the milk of cows. Journal of Dairy Science 75: 3192-3209.

Duby, R.T., Tritschler, J.P., Prange, R.W. \& Abdul-Wahid, 


\title{
AGRICULTURAL AND FOOD SCIENCE IN FINLAND
}

\author{
Shingfield, K.J. et al. Protein feeding and reproductive efficiency
}

F.T. 1984. Effect of dietary protein on urea in fluids of the reproductive tract of ewes and dairy cows. Journal of Animal Science 59 (Supplement 1): 472 (Abstract).

Edwards, J.S., Bartley, E.E. \& Dayton, A.D. 1980. Effects of dietary protein concentration on lactating cows. Journal of Dairy Science 63: 243-248.

Emanuelson, M., Ahlin, K.A. \& Wiktorsson, H. 1993. Longterm feeding of rapeseed meal and full-fat rapeseed of double low cultivars to dairy cows. Livestock Production Science 33: 199-214.

Emanuelson, U., Andersson, L. \& Alenius, S. 1989. Milk components as routine indicators of sub-clinical diseases and use in epidemiological research. Proceedings of the Society of Veterinary Epidemiology and Medicine. p. 117-127.

Eriksson, T. \& Gustafsson, A.H. 1998. En utvärdering av mjölkureavärden på individnivå från introduktionåret 96-97 i kokontrollen. Svensk husdjursskötsel, Djurböndernas kunskapsföretag. Rapport Nr. 1, 1998. 25 p.

Elrod, C.C. \& Butler, W.R. 1993. Reduction of fertility and alteration of uterine $\mathrm{pH}$ in heifers fed excess ruminally degradable protein. Journal of Animal Science 71: 694-701.

- , Van Amburg, M. \& Butler, W.R. 1993. Alterations of $\mathrm{pH}$ in response to increased dietary protein in cattle are unique to the uterus. Journal of Animal Science 71: 702-706.

Erb, R.E., Gaverick, H.A., Randel, R.D., Brown, B.L. \& Callahan, C.J. 1976. Profiles of reproductive hormones associated with fertile and nonfertile inseminations of dairy cows. Theriogenology 5: 227-242.

Ferguson, J.D. \& Chalupa, W. 1989. Symposium: Interactions of nutrition and reproduction. Impact of protein nutrition on reproduction in dairy cows. Journal of Dairy Science 72: 746-766.

- , Galligan, D.T., Blanchard, T. \& Reeves, M. 1993. Serum urea nitrogen and conception rate: the usefulness of test information. Journal of Dairy Science 76: 3742-3746.

- Blanchard, T., Galligan, D.T., Hoshall, D.C. \& Chalupa, W. 1988. Infertility in dairy cattle fed a high percentage of protein degradable in the rumen. Journal of the American Veterinary Medical Association 192: 659-662.

Folman, Y., Neumark, H., Kaim, M. \& Kaufmann, W. 1981. Performance, rumen and blood metabolites in highyielding cows fed varying protein percents and protected soyabean. Journal of Dairy Science 64: 759768.

- , Rosenberg, M., Ascarelli, I., Kaim, M. \& Herz, Z. 1983. The effect of dietary and climatic factors on fertlity and on progesterone and oestradiol-17 $\beta$ levels in dairy cows. Journal of Steroid Biochemistry 19: 863868.

- , Rosenberg, M., Herz, Z. \& Davidson, M. 1973. The relationship between plasma progesterone concentration and conception in postpartum dairy cows maintained on two levels of nutrition. Journal of $R e$ production and Fertility 34: 267-278.

Fonseca, F.A., Britt, J.H., McDaniel, B.T., Wilk, J.C. \& Rakes, A.H. 1983. Reproductive traits of Holsteins and Jerseys. Effect of age, milk yield and clinical abnormalieson involution of cervix and uterus, ovulation, estrous cycle, detection of oestrus, conception rate and days open. Journal of Dairy Science 66: 1128-1147.

Garcia-Bojalil, C.M., Staples, C.R., Risco, C.A., Savio, J.D. \& Thatcher, W.W. 1998. Protein degradability and calcium salts of long-chain fatty acids in the diets of lactating dairy cows. Reproductive responses. Journal of Dairy Science 81: 1385-1395.

- , Staples, C.R., Thatcher, W.W. \& Drost, M. 1994. Protein intake and development of ovarian follicles and embryos of superovulated nonlactating dairy cows. Journal of Dairy Science 77: 2537-2548.

Garnsworthy, P.C. 1988. The effect of energy reserve at calving on performance of dairy cows. In: Garnsworthy, P.C. (ed). Lactation and Nutrition in the Dairy Cow. Butterworths, London. p. 157-170.

Giesecke, D., Ehrentreich, L., Stangassinger, M. \& Ahrens, F. 1994. Mammary and renal excretion of purine metabolites in relation to energy intake and milk yield in dairy cows. Journal of Dairy Science 77: 2376-2381.

Gilbert, R.O., Shin, S.T., Rabuffo, T.S. \& Chandler, S.K. 1996. An in vitro model for the study of bovine endometrial physiology and pathophysiology. Proceedings of the Thirteenth International Congress on Animal Reproduction and Artificial Insemination, Sydney, Australia. p. II-1.

Gustafsson, A.H. \& Carlsson, J. 1993. Effects of silage quality, protein evaluation systems and milk urea content on milk yield and reproduction in dairy cows. Livestock Production Science 37: 91-105.

- \& Palmquist, D.L. 1993. Diurnal variation of rumen ammonia, serum urea, and milk urea in dairy cows at high and low yields. Journal of Dairy Science 76 : 475-484.

Heikkilä, T., Toivonen, V. \& Huhtanen, P. 1998. Effects of and interactions between the extent of silage fermentation and protein supplementation in lactating dairy cows. Agricultural and Food Science in Finland 7: 329-343.

Heinonen, K., Ettala, E. \& Alanko, M. 1988. Effect of postpartum live weight loss on reproductive functions in dairy cows. Acta Veterinaria Scandinavica 29: 249254.

Henniawati \& Fletcher, I.C. 1986. Reproduction in Indonesian sheep and goats at two levels of nutrition. Animal Reproduction Science 12: 77-84.

Henning, P.H., Steyn, D.G. \& Meissner, H.H. 1993. Effect of synchronization of energy and nitrogen supply on ruminal characteristics and microbial growth. Journal of Animal Science 71: 2516-2528.

Hibbitt, K.G. 1984. Effect of protein on the health of dairy cows. In: Haresign, W. \& Cole, D.J.A. (eds). Recent Advances in Animal Nutrition. Butterworth, London. p. 184-195.

Hof, G., Vervoorn, M.D., Lenaers, P.J. \& Tamminga, S. 1997. Milk urea nitrogen as a tool to monitor the protein nutrition of dairy cows. Journal of Dairy Science 80: 3333-3340.

Howard, H.J., Aalseth, E.P., Adams, G.D. \& Bush, L.J. 
Vol. 8 (1999): 365-392.

1987. Influence of dietary protein on reproductive performance of dairy cows. Journal of Dairy Science 70: 1563-1571.

Huhtanen, P. 1998a. Supply of nutrients and productive responses in dairy cows given diets based on restrictively fermented grass silage. Agricultural and Food Science in Finland 7: 219-250.

- 1998b. A comparison of protein evaluation systems used in Nordic countries. In: Kärt, O. (ed). Proceedings of the International Conference of Animal Nutrition in Tartu. Estonian Agricultural University, Estonia, 28-29 May 1998. p. 7-11.

- \& Heikkilä, T. 1996. Effects of physical treatment of barley and rapeseed meal in dairy cows given grass silage-based diets. Agricultural and Food Science in Finland 5: 399-412.

-, Vanhatalo, A \& Varvikko, T. 1998. Enzyme activities of rumen particles and feed samples incubated in situ with differing types of cloth. British Journal of Nutrition 79: 161-168.

Hurley, L.S. \& Mutch, P.B. 1973. Prenatal and postnatal development after transitory gestational zinc deficiency in rats. Journal of Nutrition 103: 649-1260.

- , Cosens, G. \& Theriault, L.L. 1976. Teratogenic effects of magnesium deficiency in rats. Journal of Nutrition 106: 1254-1260.

Jacques, J.A., Poppell, J.W. \& Jeltsch, R. 1959. Solubility of ammonia in human plasma. Journal of Applied Physiology 14: 255.

Jordan, E.R., Chapman, T.E., Holtan, D.W. \& Swanson, L.V. 1983. Relationship of dietary crude protein to composition of uterine secretions and blood in highproducing postpartum dairy cows. Journal of Dairy Science 66: 1854-1862.

- \& Swanson, L.V. 1979a. Effect of crude protein on reproductive efficiency, serum total protein, and albumin in the high-producing dairy cow. Journal of Dairy Science 62: 58-63.

- \& Swanson, L.V. 1979b. Serum progesterone and luteinizing hormone in dairy cattle fed varying levels of crude protein. Journal of Animal Science 48: 11541158.

Juneja, S.C. \& Arora, S.P. 1989. Occurrence of oestrus depressed by undernutrition in crossbred cows. Indian Journal of Animal Science 6: 194-199.

Kaim, M., Folman, Y. \& Neumark, H. 1983. The effect of protein intake and lactation number on postpartum body weight loss and reproductive performance of dairy cows. Animal Production 37: 229-235.

Karjantarkkailutulokset 1993. (Results of milk recording in Finland 1993, in Finnish) Maaseutukeskusten Liiton julkaisuja no 876, Helsinki, Finland. p. 41.

Kaur, H. \& Arora, S.P. 1995. Dietary effects on ruminant livestock reproduction with particular reference to protein. Nutrition Research Reviews 8: 121-136.

Kaustell, K., Mäntysaari, E.A. \& Huhtanen, P. 1998. Concentrate feeding and milk yield based on field data of milk recorded herds. Agricultural and Food Science in Finland 7: 423-436.

Kelly, J.M., Park, H., Summers, M. \& Milligan, L.P. 1993. Interactions between protein and energy metabolism. In: Forbes, J.M. \& France, J. (eds). Quantitative as- pects of Ruminant Digestion and Metabolism. CAB International, Oxon, UK. p. 341-362.

Kim, K.H., Oh, Y.-G., Choung, J.J. \& Chamberlain, D.G. 1999. Effects of varying degrees of synchrony of energy and nitrogen release in the rumen on the synthesis of microbial protein in cattle consuming grass silage. Journal of the Science of Food and Agriculture 79: 833-838.

Klucinski, W. \& Targowski, S.P. 1984. Ammonia toxicity for mammalian and avian lymphocytes from blood. Immunopharmacology 8: 47.

Kuni, N. \& Pirinen, P. 1988. A study of ovarian activity and uterine involution in Finncattle. Suomen Eläinlääkärilehti 94: 342-347.

Ladenheim, R.G., Tesone, M. \& Charreau, E.H. 1984. Insulin action and characterization of insulin receptors in rat luteal cells. Endocrinology 115: 752-756.

Lewis, D. 1957. Blood-urea concentration in relation to protein utilisation in the ruminant. Journal of Agricultural Science, Cambridge 48: 438-446.

Madsen, J., Hvelplund, T., Weisbjerg, M.R., Bertilsson, J., Olsson, I., Spörndly, R., Harstad, O.M., Volden, H., Tuori, M., Varvikko, T., Huhtanen, P. \& Olafsson, B.L. 1995. The AAT/PBV protein evaluation system for ruminants. A revision. Norwegian Journal of Agricultural Sciences Supplement No. 19: 1-37.

Mauer, R.R. \& Beier, H.M. 1976. Uterine proteins and development in vitro of rabbit preimplantation embryos. Journal of Reproduction and Fertility 48: 3341.

McClure, T.J. 1970. An experimental study on the causes of a nutritional and lactational stress infertility of pasture-fed cows, associated with loss of bodyweight at about the time of mating. Research in Veterinary Science 11: 247-254.

McRae, A.C. 1984. The blood-uterine lumen barrier and its possible significance in early embryo development. Oxford Reviews of Reproductive Biology 6: 129-173.

Mehrez, A.Z. \& Ørskov, E.R. 1977. A study of the artificial fibre bag technique for the determination the digestibility of feeds in the rumen. Journal of Agricultural Science, Cambridge 88: 645-653.

Metcalf, J.A., Wray-Cahen, D., Chettle, E.E., Sutton, J.D., Beever, D.E., Crompton, L.A., MacRae, J.C., Bequette, B.J. \& Backwell, F.R.C. 1996. The effect of dietary crude protein as protected soybean meal on mammary metabolism in the lactating dairy cow. Journal of Dairy Science 79: 603-611.

McCarthy, R.D., Klusmeyer, T.H., Vicini, J.L., Clark, J.H. \& Nelson, D.R. 1989. Effects of source of protein and carbohydrate on ruminal fermentation and passage of nutrients to the small intestine of lactating cows. Journal of Dairy Science 72: 2002-2010.

Michalet.Doreau, B. \& Ould-Bah, M.Y. 1992. In vitro and in situ methods for the estimation of dietary nitrogen degradability in the rumen: a review. Animal Feed Science and Technology 40: 57-86.

Miettinen, P.V.A. 1990a. Metabolic balance and reproductive performance in Finnish dairy cows. Journal of Veterinary Medicine Series A 37: 417-424.

- $1990 b$. Uterine involution in Finnish dairy cows. Acta Veterinaria Scandinavica 31: 181-185. 
Shingfield, K.J. et al. Protein feeding and reproductive efficiency

- 1990c. Effect of feeding on reproductive performance in Finnish dairy cows. Acta Veterinaria Scandinavica 31: 453-458.

- 1991. Correlation between energy balance and fertility. Acta Veterinaria Scandinavica 32: 189-196.

- \& Juvonen, R.O. 1990. Diurnal variations of serum and milk urea levels in dairy cows. Acta Agriculturae Scandinavia 40: 289-296.

NRC 1985. Ruminant Nitrogen Usage. National Research Council. National Academy Press, Washington, D.C. $138 \mathrm{p}$.

- $\quad$ 1988. Nutrient Requirements of Dairy Cattle. $6^{\text {th }}$ edition. National Academy Press, Washington, D.C. 147 p.

Nocek, J.E. 1988. In situ and other methods to estimate ruminal protein and energy digestibility: a review. Journal of Dairy Science 71: 2051-2069.

Nousiainen, J. 1997. Maidon ureapitoisuuden vaikutus lehmien tiinehtyvyyteen. Kotieläintieteen päivät 1997. Maaseutukeskusten Liiton julkaisuja 914: 87-90.

Oldham, J.D. 1984. Protein-energy interrelationships in dairy cows. Journal of Dairy Science 67: 1090-1114.

Oltenacu, P.A., Britt, J.H., Braun, R.K. \& Mellenberger, R.W. 1984. Effect of health status on culling and reproductive performance of holstein cows. Journal of Dairy Science 67: 1783-1792.

Ørskov, E.R. \& McDonald, I. 1979. The estimation of protein degradability in the rumen from incubation measurements weighted according to rate of passage. Journal of Agricultural Science, Cambridge 92: 499503.

Parker, N.J. \& Blowey, R.W. 1976. Investigations into the relationship of selected blood components to nutrition and fertility of the dairy cow under commercial farm conditions. Veterinary Record 98: 394-404.

Payne, J.M., Dew, S.M., Manston, R. \& Faulks, M. 1970. The use of a metabolic profile test in dairy herds. Veterinary Record 87: 150-158.

Pehrson, B., Plym Forshell, K. \& Carlsson, J. 1992. The effect of additional feeding on the fertility of high-yielding dairy cows. Journal of Veterinary Medicine A 39: 187-192.

Piatkowski, B., Voigt, J. \& Girschewski, H. 1981. Influence of crude protein on fertility and on the urea content in the body fluids of high-yielding cows. Archives of Animal Nutrition 31: 497-504.

Plym Forshell, K., Andersson, L. \& Pehrson, B. 1991. The relationships between the fertility of dairy cows and clinical and biochemical measurements, with special reference to plasma glucose and milk acetone. Journal of Veterinary Medicine A 38: 608-616.

Rajamäki, S. \& Rauramaa A. 1984. The automated determination of urea in milk. Finnish Chemical Letters 2: $47-48$.

Refsdal, A.O. 1983. Urea in bulk milk as compared to the herd mean of urea in blood. Acta Veterinaria Scandinavica 24: 518-520.

Rinne, M., Jaakkola, S., Heikkilä, T., Huhtanen, P. \& Toivonen, V. 1995. Nurmirehun sulavuuden ja väkirehun yhdysvaikutukset lypslehmillä. Kotieläintieteen päivät 1995. Maaseutukeskusten Liiton julkaisuja 888: 4146.

Robinson, J.J. 1986. Nutrition and embryo loss in farm animals. In: Screenan, J.M. \& Diskin, M.G. (eds). Embryonic Mortality in Farm Animals. Dordrecht, Martinus Nijhoff. p. 235-248.

- 1990 . Nutrition in the reproduction of farm animals. Nutrition Research Reviews 3: 253-276.

Ropstad, E. \& Refsdal, A.O. 1987. Herd reproductive performance related to urea concentration in bulk milk. Acta Veterinaria Scandinavica 28: 55-63.

Rusche, W.C., Cochran, R.C., Corah, L.R., Stevenson, J.S., Harmon, D.L., Brandt, R.T., Jr. \& Minton, J.E. 1993. Influence of source and amount of dietary protein on performance, blood metabolites, and reproductive function of primiparous beef cows. Journal of Animal Science 71: 557-563.

Rutter, L.M. \& Manns, J.G. 1987. Hypoglycaemia alters pulsatile luteinizing hormone secretion in the postpartum beef cow. Journal of Animal Science 64: 479488.

Saitoh, M. \& Takahashi, S. 1977. Embryonic loss and progesterone metabolism in rats fed a high energy diet. Journal of Nutrition 107: 230-234.

Salo, M.-L., Tuori, M. \& Kiiskinen, T. 1990. Rehutaulukot ja ruokintanormit. Märehtijät-siat-siipikarja-turkiseläimet. (Finnish feed tables and feeding recommendations, in Finnish). Helsinki 1990. 70 p.

Sasser, R.G., Williams, R.J., Bull, R.C., Ruder, C.A. \& Falk, D.G. 1988. Postpartum reproductive performance in crude protein -restricted beef cows: return to estrus and conception. Journal of Animal Science 66: 3033-3039.

Sato, H., Nishiguchi, Y. \& Kato, T. 1996. Relations between milk urea levels and conception in lactating dairy cows. Animal Science and Technology 67: 5863.

Schepers, A.J. \& Meijer, R.G.M. 1998. Evaluation of the utilization of dietary nitrogen by dairy cows based on urea concentration in milk. Journal of Dairy Science 81: 579-584.

Schrick, F.N., Inskeep, E.K. \& Butcher, R.L. 1993. Pregnancy rates for embryos transferred from early postpartum beef cows into recipients with normal estrous cycles. Biology of Reproduction 49: 617-621.

Shingfield, K.J. \& Huhtanen, P. 1998. Evaluation of nutritional factors influencing milk urea concentrations. Journal of Dairy Science 81: (Supplement 1): 316 (Abstract).

- \& Jokela, M. 1998. Maidon ureamittauksia kannattaa hyödyntää ruokinnan suunnittelussa ja seurannassa. Maito ja me 9: 26-27.

- , Huhtanen, P. \& Kaustell, K. 1997. Milk urea - It's use as a diagnostic. Kotieläintieteen päivät 1997. Maaseutukeskusten Liiton julkaisuja 914: 81-85.

Sinclair, L.A., Garnsworthy, P.C., Newbold, J.R. \& Buttery, P.J. 1993. Effect of synchronizing the rate of dietary energy and nitrogen release on rumen fermentation and microbial protein synthesis in sheep. Journal of Agricultural Science, Cambridge 120: 251263.

Smith, M. 1986. Recent advances in corpus luteum physiology. Journal of Dairy Science 69: 911-926.

Sonderman, J.P. \& Larson, L.L. 1989. Effect of dietary protein and exogenous gonadotropin-releasing hor- 


\section{AGRICULTURAL AND FOOD SCIENCE IN FINLAND}

Vol. 8 (1999): 365-392.

mone on circulating progesterone concentrations and performance of Holstein cows. Journal of Dairy Science 72: 2179-2183.

Spicer, L.J., Tucker, W.B. \& Adams, G.D. 1990. Insulinlike growth factor $-I$ in dairy cows: relationships among energy balance, body condition, ovarian activity, and estrous behavior. Journal of Dairy Science 73: 929-937.

Symonds, H.W., Mather, D.L. \& Kollis, K.A. 1981. The maximum capacity of the liver of the adult dairy cow to metabolise ammonia. British Journal of Nutrition 46: 481-486.

Tamminga, S. 1992. Nutritional management of dairy cows as a contribution to pollution control. Journal of Dairy Science 75: 345-357.

Thomas, C. \& Rae, R.C. 1988. Concentrate supplementation of silage for dairy cows. In: Garnsworthy, P.C. (ed.). Nutrition and Lactation in the Dairy Cow. Butterworths, London. p. 327-354.

Tuori, M., Kaustell, K. \& Huhtanen, P. 1998. Comparison of the protein evaluation systems of feeds for dairy cows. Livestock Production Science 55: 33-46.

Tveit, B., Lingaas, F., Svendsen, M. \& Skaastad, Ø.V. 1992. Etiology of acetomemia in Norwegian cattle. 1. Effect of ketogenic silage, season, energy level, and genetic factors. Journal of Dairy Science 715 : 2421-2432.

Villa-Godoy, A., Hughes, T.L., Emery, R.S., Chapin, L.T. \& Fogwell, R.L. 1988. Association between energy balance and luteal function in lactating dairy cows. Journal of Dairy Science 71: 1063-1072.

Visek, W.J. 1968. Some aspects of ammonia toxicity in animal cells. Journal of Dairy Science 51: 286-295.

- 1984. Ammonia: Its effects on biological systems, metabolic hormones, and reproduction. Journal of Dairy Science 67: 481-498.

Wallace, J.M., Aitken, R.P. \& Cheyne, M.A. 1996. The effect of excess rumen degradable protein during the pre, peri or post-ovulatory period on conception rate and conceptus interferon secretion in naturally cycling ewes. Animal Science 62: 181A (Abstract).

Wenninger, A. \& Distl, O. 1994. Urea and acetone in milk as indicators for nutritional fertility disorders of dairy cattle. Deutsche Tierärztliche Wochenschrift 101: 152-157.

Whitelaw, F.G., Milne, J.S., Ørskov, E.R. \& Smith, J.S. 1986. The nitrogen and energy metabolism of lactating cows given abomasal infusions of casein. British Journal of Nutrition 55: 537-556.

Whitmore, H.L. 1984. Pathophysiology of the puerperium: Management factors. Proceedings of the $10^{\text {th }}$ International Congress of Animal Reproduction and Artificial Insemination, Illinois. p. 34-40.

Wiley, J.S., Petersen, M.K., Ansotegui, R.P. \& Bellows, R.A. 1991. Production from first-calf heifers fed a maintenance or low level of prepartum nutrition and ruminally undegradable or degradable protein postpartum. Journal of Animal Science 69: 4279-4293.

Williams, J.S., Gardiner, C.S., Schuller, L.S., Swanson, L.V. \& Menino, A.R. 1987. Evaluation of uterine flushings collected from dairy cows fed two levels of crude protein. Journal of Animal Science 65 (Supplement 1): 415 (Abstract).

Youdan, P.G. \& King, J.O.L. 1977. The effects of body weight changes on fertility during the postpartum period in dairy cows. British Veterinary Journal 133: 635-641. 
Shingfield, K.J. et al. Protein feeding and reproductive efficiency

\title{
SELOSTUS
}

\section{Lypsylehmien valkuaisruokinnan ja hedelmällisyyden yhteys: kirjallisuustutkimus valkuaisruokinnan vaikutuksista Suomen olosuhteissa}

\author{
Kevin John Shingfield, Marjatta Jokela, Kaisa Kaustell, Pekka Huhtanen ja Juha Nousiainen \\ Maatalouden tutkimuskeskus ja Valio Oy
}

Tässä kirjallisuustutkimuksessa on tarkasteltu valkuaisruokinnan ja hedelmällisyyden välistä yhteyttä lypsylehmillä. Julkaistun aineiston perusteella valkuaisruokinnan vaikutus hedelmällisyyteen vaihtelee. Hedelmällisyyden parametreinä käytettiin tyhjäpäivien määrää, siemennysten määrää tiineyttä kohti ja tiinehtymisprosenttia. Vaihtelevat tulokset voivat johtua erilaisista koejärjestelyistä, tilastollisista analyysimenetelmistä, havaintojen määrästä (usein liian pieni hedelmällisyyden mittaamiseksi luotettavasti), kohdun terveydentilasta, lehmän iästä, poikimiskertojen määrästä, lehmien hoidosta ja ravintoaineiden saannista. Liian runsaan valkuaisruokinnan aiheuttamaan heikentyneeseen hedelmällisyyteen liittyy usein kudosten urea- ja ammoniakkipitoisuuden nousu, mikä huonontaa lisääntymiselinten fysiologista toimintaa, muuttaa hormonien eritystä tai lisää negatiivista energiatasetta poikimisen jälkeen. Vuoden 1993 tarkkailuaineistojen (16 051 karjaa) analysointi osoitti, että maidontuotannon optimi saavutettiin rehuannoksen raakavalkuaispitoisuuden ollessa $180 \mathrm{~g} / \mathrm{kg}$ kuiva-ainetta (ka) hedelmällisyysparametrien pysyessä lähes ennallaan. Tutkittaessa tankkimaidon ureapitoisuuden vaikutusta hedelmällisyyteen 5437 tilan aineistossa havaittiin, että tilojen väliset erot maidon ureapitoisuudessa eivät vaikuttaneet hedelmällisyyteen. Johtopäätöksenä voidaan todeta, että rehuannoksen raakavalkuaispitoisuuden nostaminen 150:stä 170 $\mathrm{g}: \mathrm{aan} / \mathrm{kg}$ ka lisää maidontuotantoa huonontamatta merkittävästi hedelmällisyyttä. 